\title{
SOURCE-AREA, PALEOWEATHERING AND PROVENANCE OF THE LATE CRETACEOUS SEQUENCES OF THE BAURU BASIN (SE BRAZIL)
}

\author{
ÁREA FONTE, PALEOINTEMPERISMO E PROVENIÊNCIA DAS SEQUÊNCIAS DO CRETÁCEO \\ SUPERIOR DA BACIA BAURU (SUDESTE DO BRASIL)
}

Nathalia Helena Secol MATTOS ${ }^{1}$, Alessandro BATEZELLI ${ }^{2}$

${ }^{1}$ School of Earth and Ocean Sciences. Cardiff University. Ain Building, Park PI, Cardiff CF10 3AT, UK.

E-mail: mattosnh@cardiff.ac.uk

${ }^{2}$ Departamento de Geologia e Recursos Naturais (DGRN) - Instituto de Geociências, Universidade Estadual de Campinas (IGe/UNICAMP). E-mails: alessandro.batezelli@gmail.com

\author{
Introduction \\ Geological Setting \\ Sampling and Methods \\ Whole-Rock and Clay Mineral Composition \\ Geochemistry \\ Major Elements \\ Trace elements \\ Rare Earth Elements (REE) \\ Tectonic setting, provenance and weathering in the Bauru Basin \\ Tectonic Setting \\ Provenance \\ Weathering \\ Discussion and Conclusions \\ Acknowledgements: \\ References
}

\begin{abstract}
Geochemical and mineralogical analyses of sandstones and mudstones from the Bauru Basin (SE Brazil) were undertaken to determine the provenance, tectonic setting and weathering during the Late Cretaceous. X-ray diffraction (XRD) analysis indicate that samples comprise of quartz, microcline and hematite. Illite, montmorillonite and palygorskite are the main clay minerals. $\mathrm{X}$-ray fluorescence (XRF) and inductively coupled plasma mass spectrometry (ICP-MS) analyses determined the main chemical composition of the rocks from the Bauru Basin. Predominant major elements include $\mathrm{SiO}_{2}, \mathrm{Al}_{2} \mathrm{O}_{3}, \mathrm{Fe}_{2} \mathrm{O}_{3}, \mathrm{MgO}, \mathrm{K}_{2} \mathrm{O}$ and $\mathrm{TiO}_{2}$, and were used to determine the rock composition and classify them as Fe-sands, litharenites, sublitharenites, wackes and shales. Trace elements, including the rare earth elements and the ratios among them determined the source area and its tectonic setting. A correlation matrix including major and trace elements and plots of major and trace elements and values for the ratios such as La/Sc (1.47-4.86), $(\mathrm{La} / \mathrm{Yb})_{\mathrm{c}}(3.86-20.44)$ and the $\mathrm{Eu}$ anomaly $\left(\mathrm{Eu} / \mathrm{Eu}^{*}=0.62-0.92\right)$, compared to data from the literature indicate the source rock is associated with a continental passive margin tectonic setting. The sedimentary succession of the Bauru Basin derived from quartzitic to granitic-gneissic rocks of stable continental areas. Chemical Index of Alteration (CIA) and Chemical Index of Weathering (CIW) values range, respectively, from 64.83 to 92.3 and 84 to 98.2 , indicating a moderate to intense weathering in the source area in a semiarid climate conditions.
\end{abstract}

Keywords: Late Cretaceous; Bauru Basin; Tectonic setting; Provenance; Geochemistry.

RESUMO - Análises geoquímicas e mineralógicas de arenitos e lamitos da Bacia do Bauru (SE Brasil) foram realizadas para determinar a proveniência, a configuração tectônica e o intemperismo durante o final do Cretáceo. A análise por difração de raios $\mathrm{X}$ (DRX) indica que as amostras são compostas por quartzo, microclina e hematita. Illita, montmorilonita e paligorskita são os principais argilominerais. As análises de fluorescência de raios X (XRF) e espectrometria de massa de plasma indutivamente acoplada (ICP-MS) determinaram a principal composição química das rochas da Bacia Bauru. Os principais elementos predominantes incluem $\mathrm{SiO}_{2}, \mathrm{Al}_{2} \mathrm{O}_{3}$, $\mathrm{Fe}_{2} \mathrm{O}_{3}, \mathrm{MgO}, \mathrm{K}_{2} \mathrm{O}$ e $\mathrm{TiO}_{2}$ e foram usados para determinar a composição das rochas e classificá-las como areias ferruginosas, litoarenitos, sublitoarenitos, grauvacas e folhelhos. Os elementos traços, incluindo os elementos de terras raras e as razões entre eles, determinaram a área fonte e sua configuração tectônica. Uma matriz de correlação incluindo elementos maiores e traços e gráficos de elementos maiores e traços e valores para as proporções de $\mathrm{La} / \mathrm{Sc}(1,47-4,86),(\mathrm{La} / \mathrm{Yb}) \mathrm{c}(3,86-20,44)$ e a anomalia de $\mathrm{Eu}(\mathrm{Eu} / \mathrm{Eu} *$ = 0,62-0,92), comparados com os dados da literatura, indicam que a rocha-fonte está associada a um ambiente tectônico de margem passiva continental. A sucessão sedimentar da Bacia do Bauru deriva de rochas quartzíticas a graníticas-gnáissicas de áreas continentais estáveis. Os valores do Índice Químico de Alteração (CIA) e do Índice Químico de Intemperismo (CIW) variam, respectivamente, de 64,83 a 92,3 e 84 a 98,2, indicando um intemperismo moderado a intenso na área de origem em condições climáticas semiáridas.

Palavras-chave: Cretáceo Superior; Bacia Bauru; Ambiente tectônico; Proveniência; Geoquímica.

\section{INTRODUCTION}

The reconstruction and interpretation of the sedimentary input from the source rock weathering to deposition is the primary purpose of provenance studies (Cox et al., 1995; Jarvis et al., 1998; Nesbitt et al., 1990; Pearce \& Jarvis,
1995). Sedimentary evolution is recorded in the geochemical characteristics of rocks at the sedimentary basin and allows the deduction of the geographical location and the mineralogical composition of the source rocks (Roser \& 
Korsch, 1988; Taylor \& McLennan, 1985), the chemical weathering and erosion dynamics (McLennan, 1993; Nesbitt \& Young (1982). Tectonic setting of sedimentary basins (Bhatia \& Crook, 1986; Roser \& Korsch, 1986), sorting processes during transport and sedimentation, and post-depositional diagenetic reactions (McLennan, 1989; Nesbitt \& Young, 1996) also influence sedimentary rocks composition.

As terrigenous fine sediments such as clay and fine-grained sandstones are transported, imobile trace elements including $\mathrm{Y}, \mathrm{Sc}, \mathrm{Th}, \mathrm{Zr}, \mathrm{Hf}, \mathrm{Nb}$, $\mathrm{Cr}$ and $\mathrm{Co}$ and rare earth elements (REE) tend to remain in the particulate load during erosion, transport and sedimentation. Thus, the characteristic trace-element distribution of the source rocks is preserved, being an effective indicator of geological processes, tectonic settings and provenance (Bhatia \& Crook, 1986; Condie et al., 2001; Cullers et al., 1979, 1988; Cullers, 2000; Fedo et al., 1995; McLennan et al., 1990; Mongelli et al., 2006; Taylor \& McLennan, 1985).

Crustal exposition of the source area is also reflected on ratios between trace and rare earth elements and the whole-rock geochemistry (Akarish \& El-Gohary, 2011; Bauluz et al., 2000; Condie \& Wronkiewicz, 1990; Condie et al.,
2001; Cullers, 2000; Fedo et al., 1995; McLennan et al., 1990; McLennan \& Taylor, 1991; Mongelli et al., 2006), allowing the identification of the depositional setting at the time of deposition (Roser \& Korsch, 1988; Taylor \& McLennan, 1985).

Mobile major elements can be used to discriminate the tectonic setting of the source area (Roser \& Korsch, 1988) and to estimate the chemical weathering degree, characterizing paleoclimates in the source area during deposition (Nesbitt \& Young, 1982).

The stratigraphic interval selected for geochemical analysis of the Bauru Basin is located in the Triângulo Mineiro area, Minas Gerais State (SE Brazil). The main objective of this paper is the mineralogical and geochemical characterization of Late Cretaceous intervals of the Bauru Basin, represented by lacustrine, fluvial and alluvial deposits.

The main results obtained from this study included the classification of dominant types of sediments in the studied area and the determination of highly-graded metamorphic rocks weathered in arid- to semi-arid conditions as the main source for the basin infill, confirming its relationship with the uplift of the Alto Parnaíba pre-Cambrian basement.

\section{GEOLOGICAL SETTING}

The Bauru Basin is a Late Cretaceous continental basin developed in the southeast of South America after the breakup of Gondwana, as a response to thermal subsidence related both to the cooling of the Early Cretaceous Serra Geral Formation basaltic lavas (Milani, 1997) and a Late Cretaceous tectonic restructuring related to the Alto Paranaiba Uplift (Batezelli, 2010) (Figure 1). This basin occupies approximately $370.000 \mathrm{Km}^{2}$ between the SE-SW regions of Brazil, with sedimentary deposition reaching a maximum thickness of $300 \mathrm{~m}$.

Based on the integration of paleontological data, stratigraphic relationships, and tectonic and magmatic events that occurred in the northern and northeastern portions of the Bauru Basin, it is proposed an Aptian-Maastrichtian age to its units (Batezelli, 2015).

The Bauru Group has been interpreted as alluvial fans and ephemeral lacustrine systems, braided, river-dominated alluvial systems (Batezelli (2003 and 2010) and Batezelli et al. (2007), megafan systems (Batezelli, 2015), and distributive fluvial system (Batezelli \& Ladeira, 2016 and Batezelli et al., 2019).

The aeolian deposits from the Caiuá unconformably underlies the Bauru Group deposits, which consists of three facies associations from the base to the top: Lacustrine Facies Association, Fluvial Facies Association and Alluvial Facies Association, which constitute lacustrine, fluvial and alluvial system tracts (Figures 2 and 3; Batezelli, 2015 and Batezelli et al., 2019).

The basal Lacustrine Facies Association consists of greenish- to reddish-gray, very finegrained silty sandstones and sandy siltites that present normal gradation and planar-parallel stratifications. Sandstones are generally massive, although some present root marks, desiccation cracks, salt crystal molds and small- to mediumsized trough cross stratifications (as much as 1.5 $m$ in length).

The thickness and sedimentological characteristics indicate a shallow lacustrine environment (playa-lake) with high sedimen- 
tation rates dominated by the suspension settling in the more internal portions. Density flows amid flood periods are responsible for the fining upwards rhythmic deposits. The root marks, salt crystal molds and contraction cracks associated with fine-grained sandy deposits with crossstratification indicate subaerial exposure in the more arid periods.

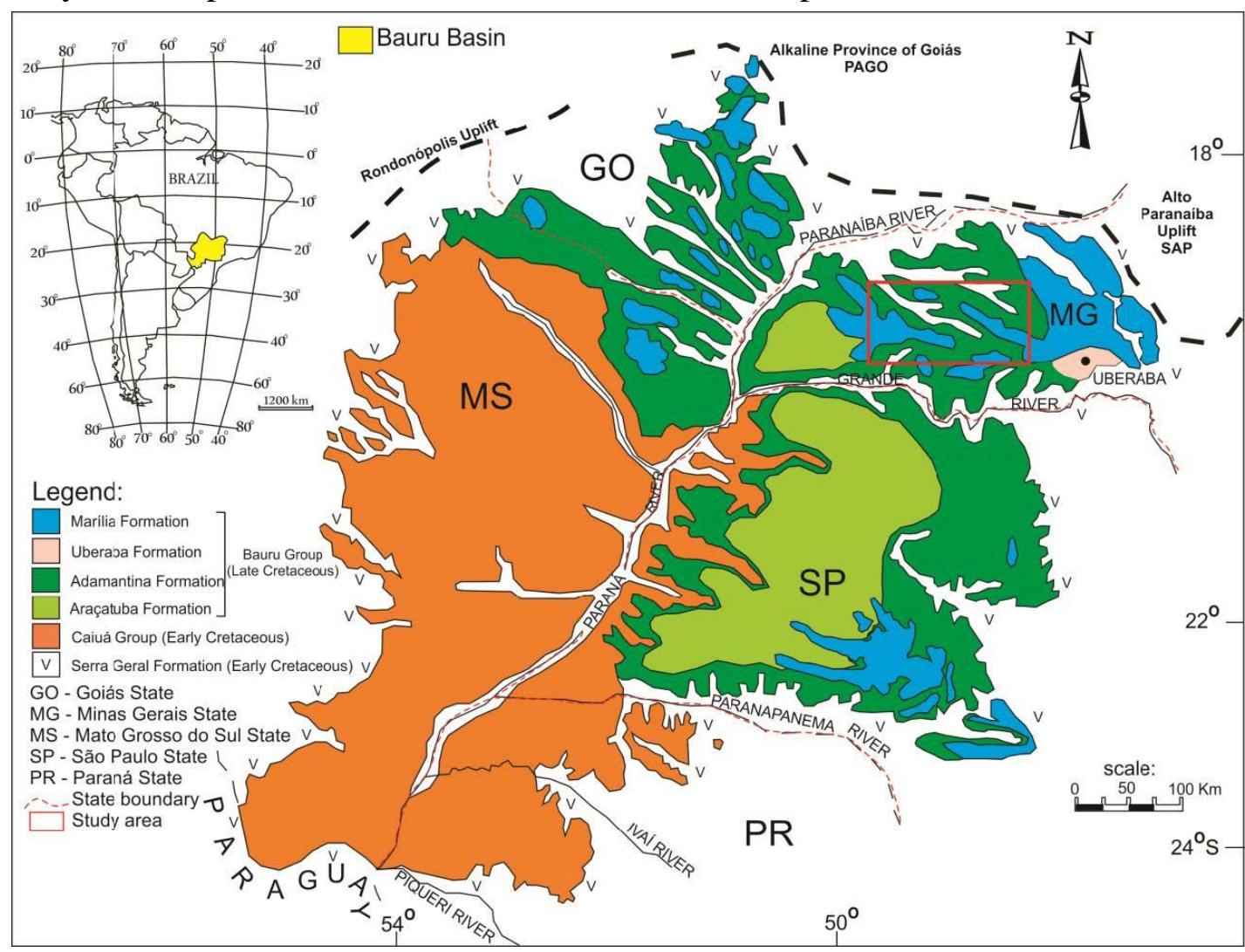

Figure 1 - Map of the Bauru Basin showing the main geological formations and the States boundaries. The red rectangle indicates the studied area, located in the Triangulo Mineiro, Minas Gerais State and dominated by sediments from the Marilia and Adamantina formations.

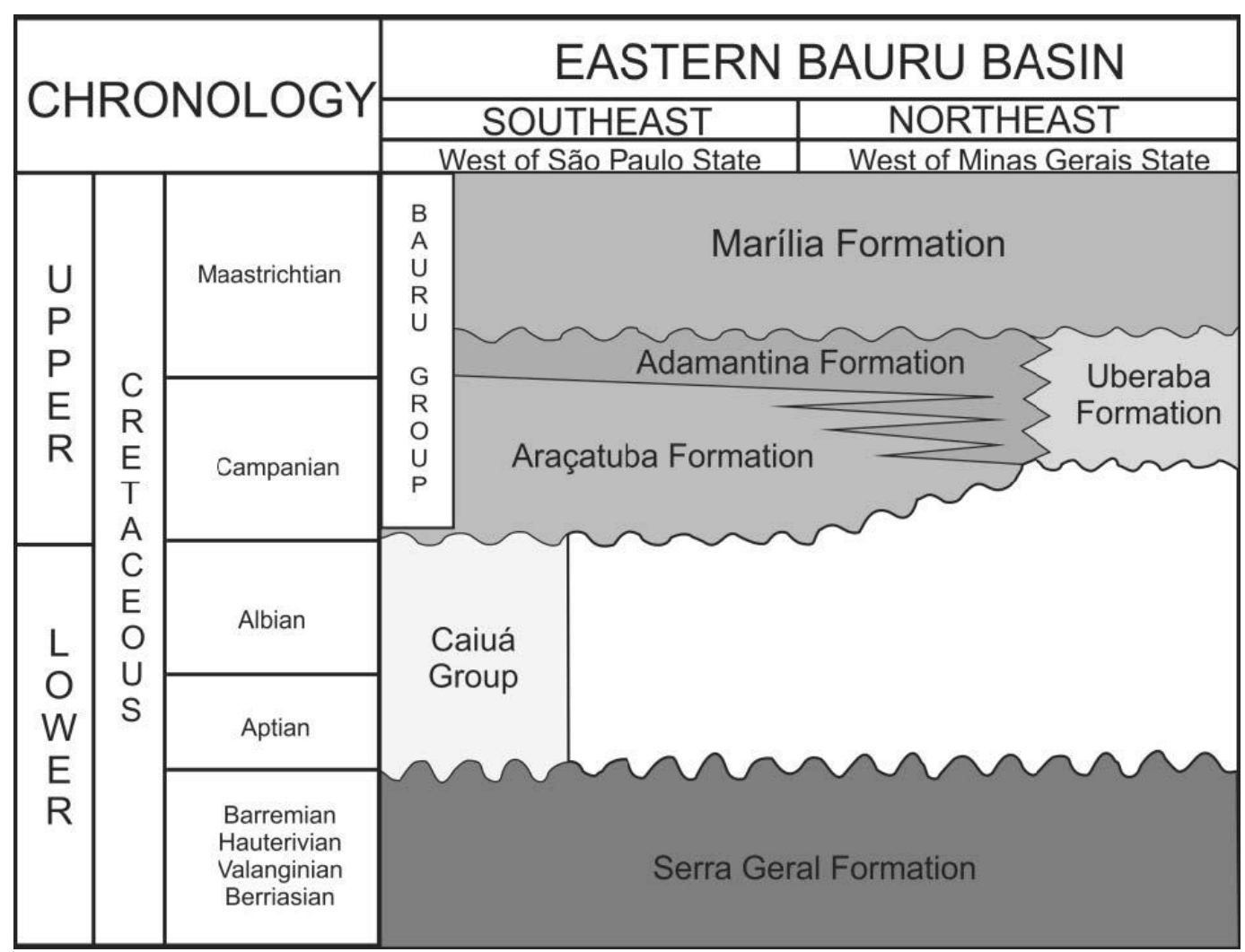

Figure 2 - Lithostratigraphic and facies associations of the Bauru Basin (Modified from Batezelli, 2003). 


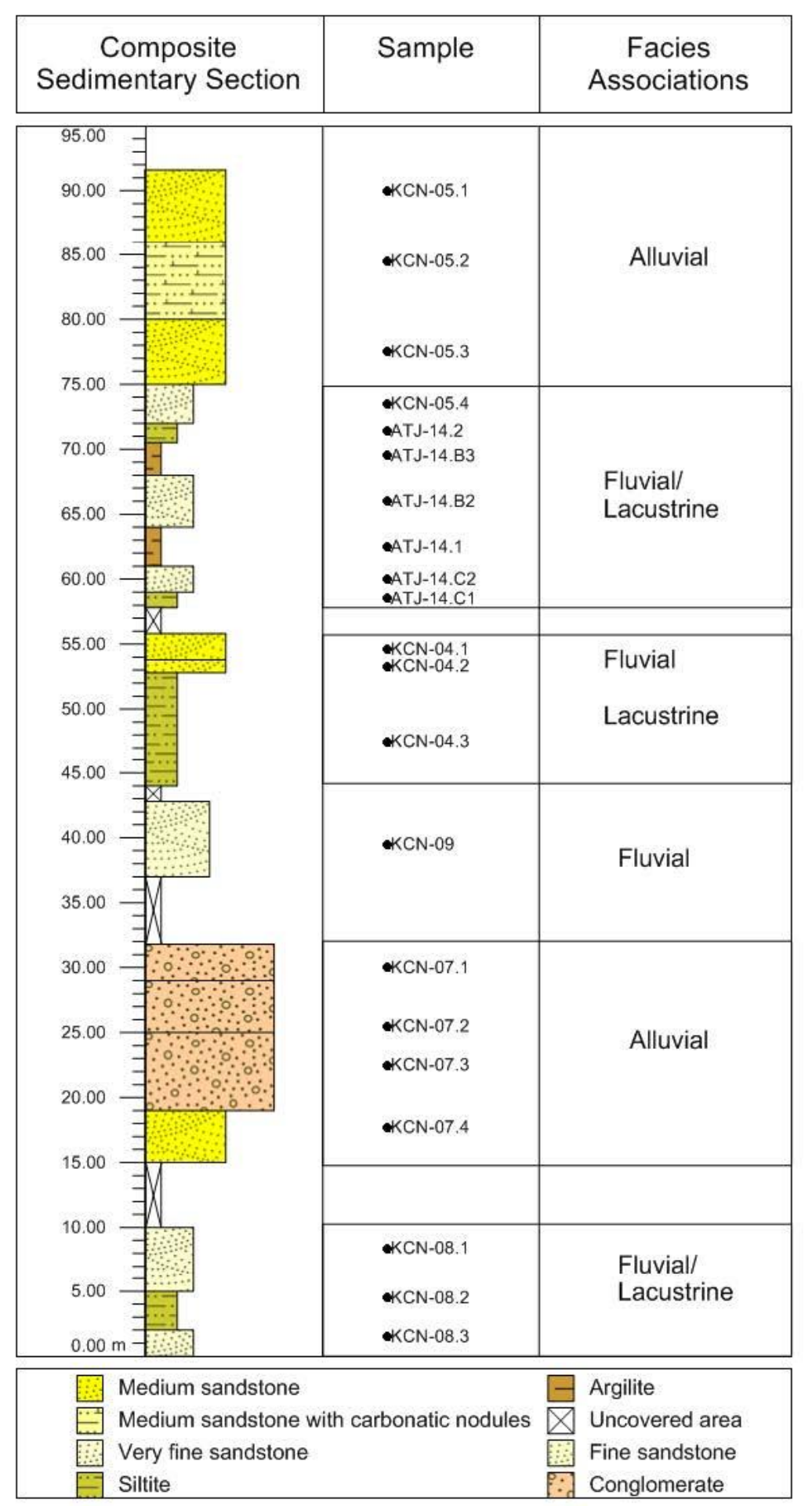

Figure 3 - Composite sedimentary section showing the location of samples and the facies associations of the studied area.

The intermediate Fluvial Facies Association overlies the Lacustrine facies association and the Serra Geral Formation basalts and comprises reddish muddy sandstones and subordinate conglomerates consisting of low to moderatesorted, rounded to sub-rounded quartz and hematite grains interbedded with mud. Moderately to weakly sorted sandy bodies vary from one to two meters in thickness and are lenticular and tabular, interbedded with centimeter-sized muddy layers.
Internally, these sandstones present crossstratification, root marks and calcium carbonate cementation. Massive sandstones and bioturbation layers are common in this unit. Channeled excavation features filled with well-sorted, very fine to fine sandstone with low-angle crossstratification and sub-millimeter- to centimetersized clay and basaltic rock intraclasts are also frequent. The presence of carbonate nodules or calcium carbonate sedimentation is common. 
Clast-supported conglomerates consisting of subangular to sub-rounded mud-pebbles exhibit lenticular geometry and thickness of up to 1.5 meters, and length of tens of meters. Those conglomerates occur at the base of fining upward sandstones, or as isolated bodies in palaeochannels.

Alluvial Facies Association comprises sandstones; paleosoils and clast-supported conglomerates Ponte Alta and Echaporã members), based on their lithology and carbonate content.

\section{SAMPLING AND METHODS}

Twenty-one (21) samples were collected from a $78 \mathrm{~m}$ thick composite sedimentary section in the SE Bauru Basin and individually identified and packed in tightly closed polyethylene bags prior to the strongly cemented by $\mathrm{CaCO}_{3}$ and $\mathrm{SiO}_{2}$ (calcretes and silcretes) (Pereira et al., 2015; Nascimento et al., 2016; Silva et al., 2015, 2016, 2017a, 2017b, Delgado et al., 2019). Sandstones are generally massive, with minor small- to medium-scale cross stratifications (up to 3-msized foresets). Sandy and conglomerate facies are organized as channels, lenticular bars and downstream accretion macroforms composing a multi-story, multilateral story and large channel complexes, interbedded with paleosols and aeolian deposits. In terms of lithostratigraphy, this facies is divided into three members (Serra da Galga, creation of thin-sections for petrographic analysis and the preparation for mineralogical and geochemical analyses, following the methods described in. Analyses were carried out at the XRD, Analytical Geochemistry and the Mass Spectrometry laboratories at the Institute of Geosciences of Unicamp (Brazil).

X-Ray Diffraction (XRD) determined the mineralogy of the whole-rock and the clay-sized fraction $(<2 \mu \mathrm{m})$, separated from bulk samples by centrifugation. This analysis was performed using a Bruker D2 Phaser diffractometer with $\mathrm{K} \alpha \mathrm{Cu}$ radiation and operated at $40 \mathrm{kV}$ and 50 $\mathrm{mA}$. The oriented clay-sized fraction went through examination under three separate conditions: air-dried; saturated in ethylene glycol and heated at $250^{\circ} \mathrm{C}$ for 8 hours.

Samples were prepared as fused glass discs and analysed on a Philips PW2400 X-Ray Fluorescence (XRF) Spectrometer for the identification of major rock elements. The instrument was calibrated using certified rock standards RGM-1, OU-6 and BRP-1. All elements gave an accuracy of $\pm 10 \%$ relative error or better for certified reference rocks.

For the trace and Rare Earth Elements analysis through Inductively Coupled Plasma Mass Spectrometry (ICP-MS), samples of 100 $\mathrm{mg}$ were digested following the procedures of $\mathrm{Yu}$ et al. (2001) and diluted to $20 \mathrm{~g}$ of ultrapure water and sent to analysis. The samples were analysed in a quadrupolar ICP-MS Thermo Xseries II model, calibrated using the international certified rock standard BRP-1.

\section{WHOLE-ROCK AND CLAY MINERAL COMPOSITION}

Petrographic analysis of eleven selected samples from Bauru Basin in the study area indicate a basic mineralogy comprised by quartz $(50 \%)$, feldspars $(15 \%)$, lithic fragments $(27 \%)$, carbonates $(5 \%)$ and heavy minerals $(3 \%)$. Samples plot into litharenite and sublitharenite fields at the McBride (1963) diagram (Figure 4). Using the geochemical classification diagram for siliciclastic rocks (Herron, 1998) and XRD data (Table 2), these samples were classified as Fesands, shale, litharenite, sublitharenite and wackes (Figure 5). According to this classification criterion, samples classified as $\mathrm{Fe}$ sands, litharenites and sublitharenites are enriched in quartz and depleted in $\mathrm{Al}_{2} \mathrm{O}_{3}, \mathrm{~K}_{2} \mathrm{O}$ and $\mathrm{TiO}_{2}$ when compared with wackes and shales (Table 3). Microcline (K-feldspar) corresponds to the second or third most common mineral in those samples, while Na-plagioclase (albite) occurs mainly on wackes and shales. Calcite and dolomite occurs in most of the samples as cements and correspond to the second most significant component in litharenite and sublitharenites.

Hematite concentrates mainly on $\mathrm{Fe}$ sandstones, although this mineral is also found on litharenite, wackes and shales.

The major clay minerals are illite, montmorillonite and palygorskite. Illite and montmorillonite occur in most of the samples, with concentrations of these clay minerals being variable with predominance of higher peaks of illite or montmorillonite. Illite has its main peak at $\mathrm{d}(001): 10.1 \AA$ and secondary peaks at $\mathrm{d}(002)$ : $5.0 \AA$ and d(003): $3.32 \AA$. Under air-dried, after saturation with ethylene glycol and after heating 
to $250^{\circ} \mathrm{C}$ conditions, illite peaks were the same, highlighting its occurrence. Montmorillonite main peak under air-dried conditions occurs at $\mathrm{d}(001): 15 \AA$. After saturation with ethylene glycol this peak shifts to $\mathrm{d}(001)$ : $17.8 \AA$ A..
Palygorskite main peak occurs at d(001): 10.4 $\AA$. After saturation with ethylene glycol, this peak shifts to $\mathrm{d}(001): 10.7 \AA$. Other peaks found for palygorskite are d(002): $6.34 \AA$ and d(003): $3.18 \AA$.

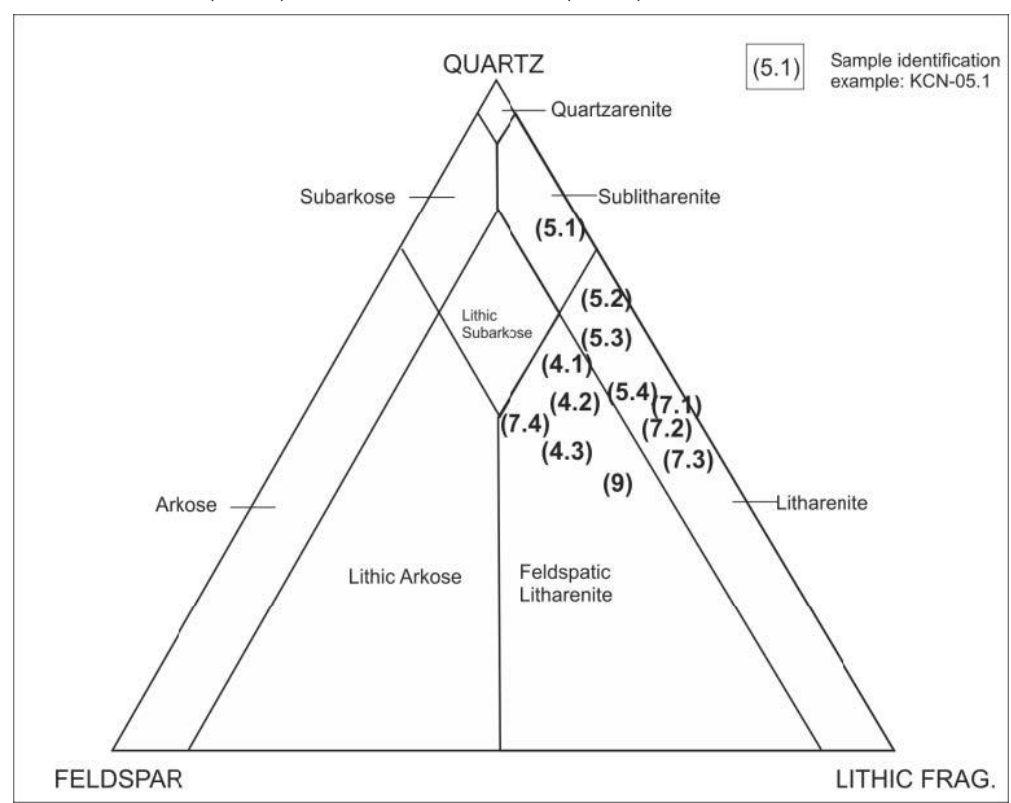

Figure 4 - Petrographic classification of selected rocks from Bauru Basin through the McBride (1963) diagram.

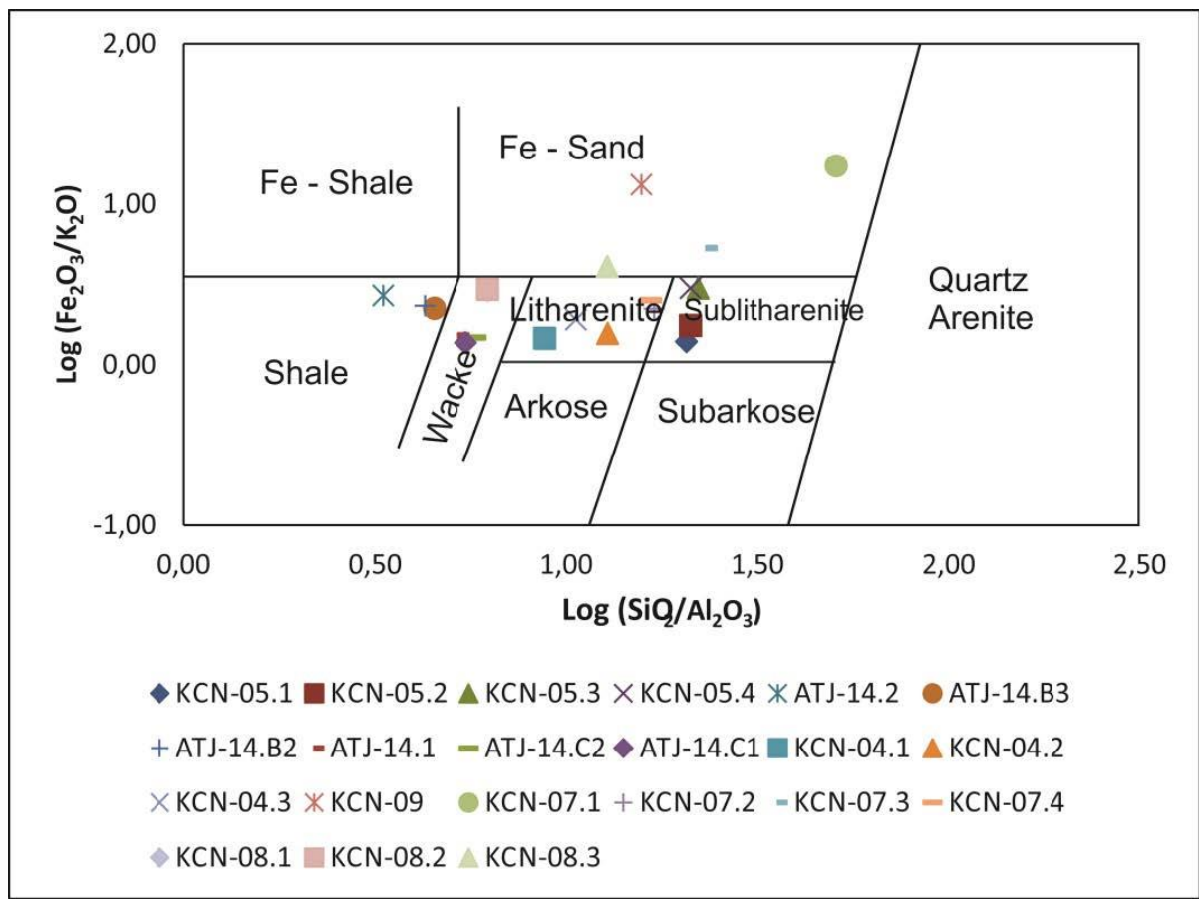

Figure 5 - Herron (1988) geochemical classification of the Bauru Basin samples in the study area, indicating the studied rocks are Litharenites, Sublitharenites, Fe-sands, wackes and shales.

\section{GEOCHEMISTRY}

The elemental concentrations of rocks from the Bauru Basin are given in Table 2. Average data of Post-Archean Australian Shale (PAAS Taylor \& McLennan 1985), considered representative of the upper continental crust composition, are also included in Table 1 and Figures 6 to 8 , as a reference for the elemental distribution of the samples during weathering and transport. A correlation matrix for all elements is shown in Table 2.

\section{Major Elements}

$\mathrm{X}$-Ray Fluorescence analysis for the study area shows high $\mathrm{SiO}_{2}$ contents for $\mathrm{Fe}$-sands and sublitharenites reflecting a mineralogy consti- 
tuted by high quartz contents (Table 3). In addition, most of the shales and wackes have high $\mathrm{Al}_{2} \mathrm{O}_{3}, \mathrm{Fe}_{2} \mathrm{O}_{3}, \mathrm{MgO}, \mathrm{K}_{2} \mathrm{O}$ and $\mathrm{TiO}_{2}$ contents, associated with their high content in phyllosilicates and clay phases. For all the samples, the $\mathrm{Al}_{2} \mathrm{O}_{3} / \mathrm{SiO}_{2}$ ratio ranges from 0.020 to 0.301 (Table 1). For shales and wackes this ratio is higher $(0.250$ and 0.173 , respectively) than for samples classified as sandstones. $\mathrm{Fe}_{2} \mathrm{O}_{3}+\mathrm{MgO}$ is also common in the composition of shales and wackes, with values ranging from 7.86 to $13.57 \%$. Intermediate to very high $\mathrm{K}_{2} \mathrm{O} / \mathrm{Na}_{2} \mathrm{O}$ contents for all samples (from 3 to 47.5) are consistent with XRD data (Table 3), indicating that microcline predominates over albite on the sediment composition.

Table 1 - Chemical composition of the classified sample groups and the PAAS (Taylor \& McLennan, 1985) values. Major elements are in weight percent and trace and rare earth elements in $\mu \mathrm{g} / \mathrm{g}$. The major, trace and rare earth elements distributions normalized to PAAS are shown in Figures 6 to 8. The correlation coefficients obtained from the matrix correlations are reported in Table 3.

\begin{tabular}{|c|c|c|c|c|c|c|}
\hline & Fe-Sands $(n=4)$ & Shale $(n=3)$ & Wacke $(n=5)$ & Litharenite $(n=5)$ & Sublitharenite $(n=4)$ & PAAS \\
\hline $\mathrm{SiO}_{2}$ & $81.55 \pm 1.48$ & $55.40 \pm 2.53$ & $66.32 \pm 1.06$ & $71.47 \pm 3.59$ & $75.20 \pm 3.50$ & 62.80 \\
\hline $\mathrm{Al}_{2} \mathrm{O}_{3}$ & $4.18 \pm 1.03$ & $13.84 \pm 0.68$ & $11.48 \pm 0.24$ & $5.80 \pm 0.80$ & $3.37 \pm 0.15$ & 18.90 \\
\hline $\mathrm{Fe}_{2} \mathrm{O}_{3}$ & $3.86 \pm 1.14$ & $8.64 \pm 0.43$ & $6.07 \pm 0.66$ & $3.18 \pm 0.34$ & $1.87 \pm 0.18$ & 7.40 \\
\hline MgO & $1.86 \pm 0.64$ & $3.35 \pm 0.36$ & $2.76 \pm 0.21$ & $2.16 \pm 0.17$ & $1.71 \pm 0.52$ & 2.20 \\
\hline $\mathrm{K}_{2} \mathrm{O}$ & $0.62 \pm 0.29$ & $3.57 \pm 0.05$ & $3.11 \pm 0.20$ & $1.70 \pm 0.23$ & $0.87 \pm 0.09$ & 3.70 \\
\hline $\mathrm{TiO}_{2}$ & $0.96 \pm 0.44$ & $1.80 \pm 0.03$ & $1.51 \pm 0.30$ & $0.87 \pm 0.14$ & $0.48 \pm 0.04$ & 1.00 \\
\hline $\mathrm{CaO}$ & $2.00 \pm 1.85$ & $1.00 \pm 0.16$ & $0.85 \pm 0.21$ & $6.65 \pm 2.65$ & $7.72 \pm 1.77$ & 1.300 \\
\hline $\mathrm{Na}_{2} \mathrm{O}$ & $0.04 \pm 0.01$ & $0.37 \pm 0.10$ & $0.36 \pm 0.08$ & $0.26 \pm 0.08$ & $0.11 \pm 0.01$ & 1.20 \\
\hline $\mathbf{P}_{2} \mathbf{O}_{5}$ & $0.05 \pm 0.01$ & $0.20 \pm 0.02$ & $0.10 \pm 0.01$ & $0.08 \pm 0.00$ & $0.04 \pm 0.01$ & 0.160 \\
\hline MnO & $0.08 \pm 0.03$ & $0.12 \pm 0.03$ & $0.12 \pm 0.03$ & $0.06 \pm 0.01$ & $0.06 \pm 0.01$ & 0.110 \\
\hline PF & $4.26 \pm 1.41$ & $11.37 \pm 0.98$ & $6.85 \pm 1.15$ & $7.25 \pm 2.08$ & $7.99 \pm 1.70$ & 6.00 \\
\hline $\mathbf{R b}$ & $19.53 \pm 8.59$ & $97.53 \pm 2.78$ & $85.86 \pm 9.89$ & $51.16 \pm 6.48$ & $23.53 \pm 2.24$ & 160.0 \\
\hline $\mathrm{Cs}$ & $0.45 \pm 0.16$ & $3.20 \pm 0.23$ & $2.68 \pm 0.39$ & $1.14 \pm 0.20$ & $0.43 \pm 0.03$ & 15.0 \\
\hline Ba & $218.13 \pm 78.85$ & $541.23 \pm 223.61$ & $564.62 \pm 46.19$ & $348.88 \pm 29.38$ & $188.70 \pm 14.83$ & 650.0 \\
\hline $\mathrm{Sr}$ & $63.33 \pm 31.03$ & $194.67 \pm 1.67$ & $139.04 \pm 11.27$ & $390.60 \pm 125.43$ & $254.35 \pm 69.49$ & 200.0 \\
\hline Th & $2.90 \pm 0.94$ & $10.70 \pm 0.50$ & $7.54 \pm 0.72$ & $7.06 \pm 2.13$ & $3.53 \pm 0.34$ & 14.6 \\
\hline $\mathbf{U}$ & $0.53 \pm 0.11$ & $1.27 \pm 0.09$ & $1.24 \pm 0.12$ & $0.82 \pm 0.05$ & $0.53 \pm 0.03$ & 3.1 \\
\hline $\mathbf{Z r}$ & $198.10 \pm 37.63$ & $260.20 \pm 12.65$ & $325.04 \pm 20.23$ & $258.98 \pm 19.81$ & $169.65 \pm 17.44$ & 210.0 \\
\hline Hf & $5.03 \pm 1.05$ & $7.33 \pm 0.43$ & $7.94 \pm 0.48$ & $6.82 \pm 0.50$ & $4.60 \pm 0.50$ & 5.0 \\
\hline $\mathbf{Y}$ & $12.53 \pm 5.47$ & $22.33 \pm 2.33$ & $20.96 \pm 3.20$ & $14.74 \pm 2.10$ & $13.28 \pm 0.87$ & 27.0 \\
\hline $\mathbf{N b}$ & $18.65 \pm 8.98$ & $39.33 \pm 2.03$ & $37.86 \pm 4.52$ & $20.26 \pm 2.13$ & $7.58 \pm 0.39$ & 19.0 \\
\hline $\mathrm{Cr}$ & $174.73 \pm 47.49$ & $243.33 \pm 38.44$ & $256.80 \pm 28.23$ & $137.74 \pm 18.71$ & $121.80 \pm 22.34$ & 110.0 \\
\hline Co & $9.53 \pm 3.46$ & $120.40 \pm 80.05$ & $64.34 \pm 11.84$ & $8.06 \pm 1.26$ & $3.73 \pm 0.28$ & 23.0 \\
\hline $\mathrm{Ni}$ & $20.38 \pm 8.58$ & $109.33 \pm 3.84$ & $60.70 \pm 18.14$ & $22.36 \pm 3.66$ & $9.10 \pm 0.79$ & 55.0 \\
\hline $\mathbf{V}$ & $63.30 \pm 26.84$ & $175.33 \pm 8.29$ & $126.28 \pm 14.46$ & $50.70 \pm 6.13$ & $31.75 \pm 6.07$ & 150.0 \\
\hline Sc & $10.65 \pm 3.00$ & $14.00 \pm 1.53$ & $12.84 \pm 1.41$ & $9.86 \pm 1.38$ & $6.20 \pm 0.84$ & 16.0 \\
\hline $\mathbf{C u}$ & $9.65 \pm 4.59$ & $47.67 \pm 6.47$ & $35.66 \pm 7.72$ & $13.98 \pm 2.55$ & $4.40 \pm 0.52$ & 50.0 \\
\hline La & $17.90 \pm 4.30$ & $55.17 \pm 2.82$ & $46.70 \pm 6.91$ & $23.92 \pm 2.04$ & $17.25 \pm 2.82$ & 38.0 \\
\hline $\mathrm{Ce}$ & $36.73 \pm 14.39$ & $104.70 \pm 10.39$ & $84.88 \pm 14.55$ & $51.76 \pm 10.43$ & $26.63 \pm 3.30$ & 80.0 \\
\hline Pr & $4.20 \pm 0.97$ & $12.63 \pm 0.98$ & $10.98 \pm 2.56$ & $5.06 \pm 0.22$ & $3.80 \pm 0.58$ & 8.9 \\
\hline Nd & $16.03 \pm 3.51$ & $47.80 \pm 3.48$ & $41.54 \pm 11.94$ & $19.30 \pm 1.04$ & $14.78 \pm 2.34$ & 32.0 \\
\hline $\mathrm{Sm}$ & $2.78 \pm 0.54$ & $7.83 \pm 0.54$ & $7.12 \pm 1.96$ & $3.32 \pm 0.24$ & $2.68 \pm 0.39$ & 5.6 \\
\hline Eu & $0.68 \pm 0.17$ & $2.00 \pm 0.25$ & $1.72 \pm 0.57$ & $0.78 \pm 0.10$ & $0.58 \pm 0.10$ & 1.1 \\
\hline Gd & $2.53 \pm 0.60$ & $6.40 \pm 0.75$ & $5.74 \pm 1.50$ & $2.98 \pm 0.33$ & $2.55 \pm 0.32$ & 4.7 \\
\hline $\mathbf{T b}$ & $0.40 \pm 0.12$ & $0.87 \pm 0.12$ & $0.80 \pm 0.19$ & $0.44 \pm 0.05$ & $0.38 \pm 0.05$ & 0.8 \\
\hline Dy & $2.55 \pm 0.99$ & $4.50 \pm 0.42$ & $4.42 \pm 0.95$ & $2.80 \pm 0.36$ & $2.50 \pm 0.19$ & 4.4 \\
\hline Ho & $0.50 \pm 0.21$ & $0.83 \pm 0.09$ & $0.82 \pm 0.15$ & $0.54 \pm 0.08$ & $0.50 \pm 0.04$ & 1.0 \\
\hline Er & $1.55 \pm 0.72$ & $2.37 \pm 0.20$ & $2.30 \pm 0.38$ & $1.68 \pm 0.21$ & $1.50 \pm 0.11$ & 2.9 \\
\hline Tm & $0.23 \pm 0.09$ & $0.37 \pm 0.07$ & $0.32 \pm 0.05$ & $0.22 \pm 0.04$ & $0.20 \pm 0.00$ & 0.4 \\
\hline $\mathbf{Y b}$ & $1.60 \pm 0.77$ & $2.30 \pm 0.20$ & $2.32 \pm 0.24$ & $1.76 \pm 0.18$ & $1.53 \pm 0.11$ & 2.8 \\
\hline Lu & $0.23 \pm 0.09$ & $0.33 \pm 0.03$ & $0.32 \pm 0.02$ & $0.24 \pm 0.04$ & $0.23 \pm 0.03$ & 0.4 \\
\hline
\end{tabular}

São Paulo, UNESP, Geociências, v. 38, n. 4, p. 943 - 960, 2019 
Table 2 - Correlation matrix of major, trace and rare earth elements for the study area.

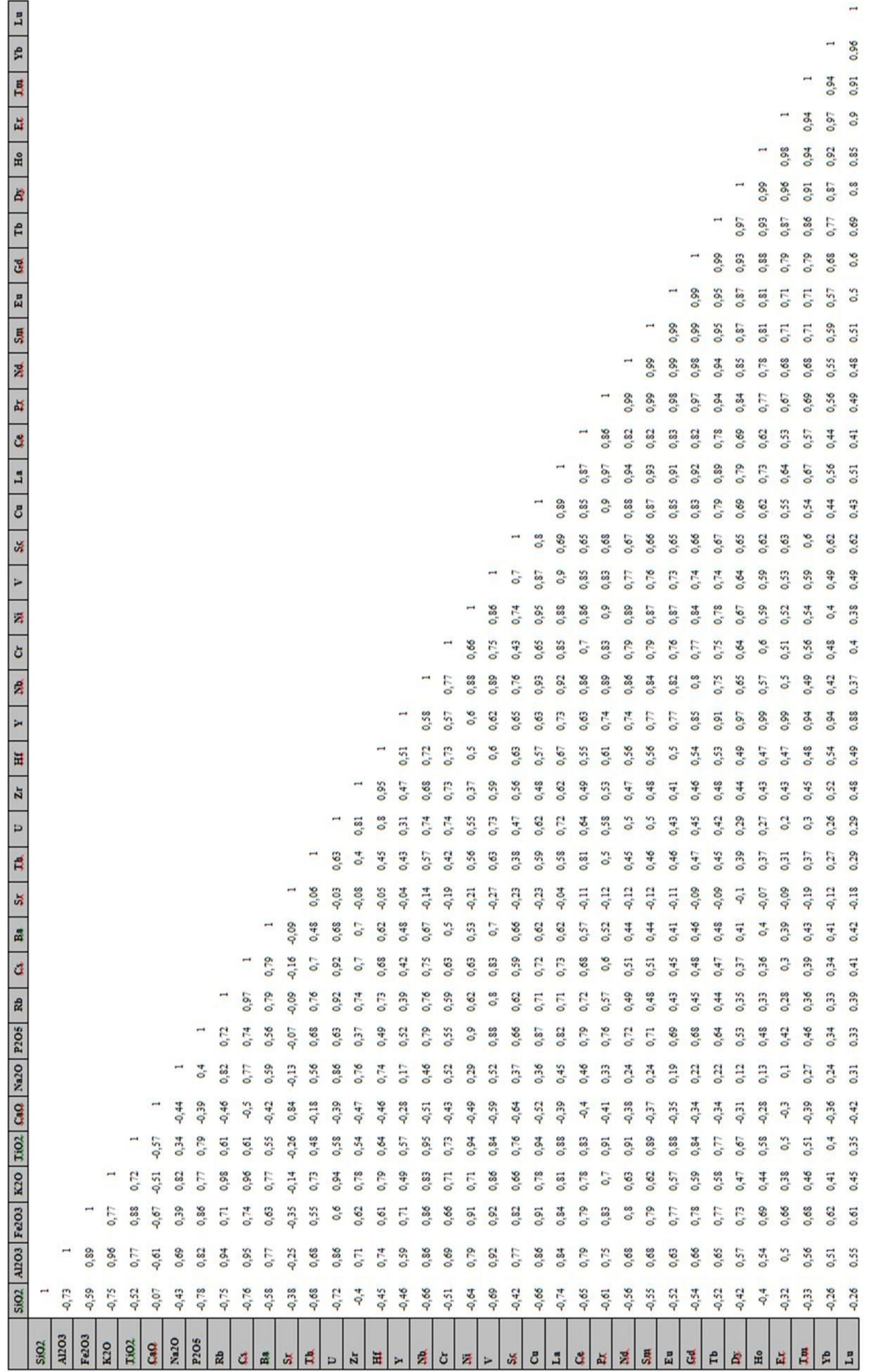


Table 3: Resultant mineralogical composition of the analysed samples.

\begin{tabular}{|c|c|c|c|}
\hline Sample & Mineralogy & Clay Minerals & Classification \\
\hline KCN-05.1 & Quartz, calcite, microcline & Montmorillonite/Illite & Sublitharenite \\
\hline $\mathrm{KCN}-05.2$ & Quartz, dolomite, calcite, microcline & Palygorskite/Montmorillonite/Illite & Sublitharenite \\
\hline KCN-05.3 & Quartz, calcite, microcline & Palygorskite/Illite/Montmorillonite & Sublitharenite \\
\hline KCN-05.4 & Quartz, calcite, microcline & Palygorskite/Montmorillonite/Illite & Sublitharenite \\
\hline ATJ-14.2 & Quartz, microcline, calcite, hematite & Illite/Montmorillonite & Shale \\
\hline ATJ-14.B3 & Quartz, microcline, calcite & Illite/Montmorillonite & Shale \\
\hline ATJ-14.B2 & Quartz, microcline, albite, calcite & Illite/Montmorillonite & Shale \\
\hline ATJ-14.1 & Quartz, albite, microcline, calcite & Illite/Montmorillonite & Wacke \\
\hline ATJ-14.C2 & Quartz, microcline, albite, dolomite & Illite/Montmorillonite & Wacke \\
\hline ATJ-14.C1 & Quartz, microcline, albite, calcite & Illite/Montmorillonite & Wacke \\
\hline KCN-04.1 & Quartz, microcline, calcite & Montmorillonite & Litharenite \\
\hline $\mathrm{KCN}-04.2$ & Quartz, microcline, calcite, dolomite & Montmorillonite/Illite & Litharenite \\
\hline KCN-04.3 & Quartz, calcite, microcline & Illite/Montmorillonite & Litharenite \\
\hline KCN-09 & Quartz, microcline, hematite & Illite/Montmorillonite & Fe-sand \\
\hline KCN-07.1 & Quartz, calcite, hematite & Palygorskite/Illite & Fe-sand \\
\hline KCN-07.2 & Quartz, calcite, microcline & Montmorillonite/Palygorskite & Litharenite \\
\hline KCN-07.3 & Quartz, hematite, microcline & Palygorskite & Fe-sand \\
\hline KCN-07.4 & Quartz, calcite, microcline, hematite, albite & Palygorskite/Illite & Litharenite \\
\hline KCN-08.1 & Quartz, hematite, microcline & Illite/Montmorillonite & Wacke \\
\hline KCN-08.2 & Quartz, hematite, microcline & Illite/Montmorillonite & Wacke \\
\hline KCN-08.3 & Quartz, hematite, microcline & Montmorillonite & Fe-sand \\
\hline
\end{tabular}

The elemental correlation matrix (Table 2) indicates a strong negative correlation between $\mathrm{SiO}_{2}$ and $\mathrm{A}_{12} \mathrm{O}_{3}, \mathrm{~K}_{2} \mathrm{O}$ and $\mathrm{P}_{2} \mathrm{O}_{5}(-0.73,-0,75$ and -0.78, respectively). Moderate negative correlations occur between $\mathrm{SiO}_{2}$ and $\mathrm{Fe}_{2} \mathrm{O} 3$, $\mathrm{MgO}$ and $\mathrm{TiO}_{2}$. While $\mathrm{Na}_{2} \mathrm{O}$ and $\mathrm{MnO}$ do not show a clear correlation with $\mathrm{SiO}_{2}, \mathrm{CaO}$ has a very small negative correlation with $\mathrm{SiO}_{2}(\mathrm{r}=$ $0.065)$.

A negative correlation for $\mathrm{Al}_{2} \mathrm{O}_{3}$ versus $\mathrm{SiO}_{2}$ and $\mathrm{CaO}$ and $\mathrm{Sr}$ was also observed (Table 2). Strong positive correlations between $\mathrm{Al}_{2} \mathrm{O}_{3}$ and $\mathrm{Fe}_{2} \mathrm{O}_{3}, \mathrm{~K}_{2} \mathrm{O}, \mathrm{TiO}_{2} \mathrm{Na}_{2} \mathrm{O}$ and $\mathrm{P}_{2} \mathrm{O}_{5}$ reflect the occurrence of feldspars and illite and montmorillonite in the sediment composition. Fe-sands, sublitharenites and litharenites are enriched in $\mathrm{CaO}$, which has a moderate correlation with the loss on ignition (LOI) $(r=0.54$, Table 2$)$, suggesting that $\mathrm{LOI}$ and $\mathrm{CaO}$ are incorporated into these sands as a calcite cement. High LOI percentages are due to the intensive volatile $\mathrm{CO}_{2}$ releasing during the calcination of samples at $1000{ }^{\circ} \mathrm{C}$.

Those samples are also enriched in $\mathrm{SiO}_{2}$ when compared with the upper continental crust composition (Figure 6). The $\mathrm{SiO}_{2}$ values for wackes and shales are similar to slightly depleted in relation to the reference values. There is an overall $\mathrm{Al}_{2} \mathrm{O}_{3}$ depletion related to PAAS contents for all the samples, with a very small amount of $\mathrm{Al}_{2} \mathrm{O}_{3}$ in litharenites, $\mathrm{Fe}$-sands, and sublitharenites (Figure 6).

Only shales are enriched in $\mathrm{Fe}_{2} \mathrm{O}_{3}$ when compared with the PAAS composition. Shales and wackes are also enriched in $\mathrm{MgO}$ and $\mathrm{TiO}_{2}$. $\mathrm{Fe}$-sands, litharenites and sublitharenites are depleted in $\mathrm{MgO}, \mathrm{P}_{2} \mathrm{O}_{5}$ and $\mathrm{MnO}$ while shales and wackes show values enriched to slightly depleted in relation to the upper continental crust composition.

\section{Trace elements}

Results of ICP-MS analysis for study area indicate a depletion of large ion lithophile Elements (LILE: Rb, Cs, Ba, Sr, Th and U) when compared with the upper continental crust composition (Figure 7). The only exception is Strontium, which occurs in a higher amount in litharenites and sublitharenite samples when compared with the PAAS composition. Wackes and $\mathrm{Fe}$-sand also show $\mathrm{Sr}$ values in their composition higher than the PAAS. Sr has a high positive correlation coefficient with $\mathrm{MgO}$ and $\mathrm{CaO}$, and a low correlation with $\mathrm{Al}_{2} \mathrm{O}_{3}$, indicating its distribution is mainly controlled by post- 
depositional carbonates. Other LILE have significant correlation coefficients with $\mathrm{Al}_{2} \mathrm{O}_{3}$, including $\mathrm{Cs}, \mathrm{Rb}$ and $\mathrm{U}$, suggesting the distribution of those elements control the occurrence of phyllosilicates and clay minerals. Depletion of LILE respective to the PAAS composition also reflects the role of weathering in the source area.

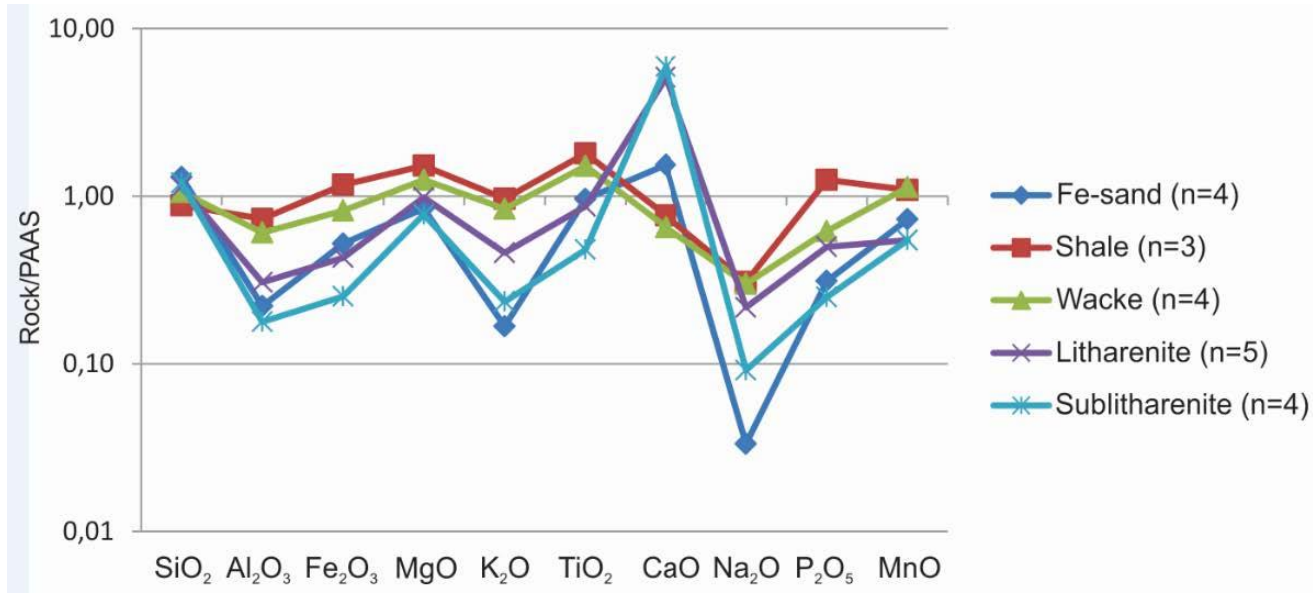

Figure 6 - Post-Archean Australian shale (PAAS) normalized values for the major elements from the Bauru Basin rocks in the studied area.

When considering the high field strength elements (HFSE: Y, Zr, Nb, Hf), sediments classified as shales, wackes and litharenites are enriched in $\mathrm{Zr}$ and $\mathrm{Hf}$, while $\mathrm{Fe}$-sands and sublitharenites have average values similar to the composition of the upper continental crust (Figure 7). Zr has a positive correlation with Hf, $\mathrm{Y}$ and $\mathrm{Nb}$ and Rare Earth Elements. All lithologies are depleted in Y, while sublitharenites shows a $\mathrm{Nb}$ depletion pattern (Figure 7). Average $\mathrm{Nb}$ contents for shales and wackes differ considerably from the upper continental crust composition while $\mathrm{Fe}$-sands and litharenites have average $\mathrm{Nb}$ values similar to PAAS. The concentrations of transition trace elements (TTE: $\mathrm{Cr}, \mathrm{Co}, \mathrm{Ni}, \mathrm{V}, \mathrm{Sc}, \mathrm{Cu}$ ) vary in shales, wackes, Fe-sands, litharenites and sublitharenites. The amount of $\mathrm{Cr}$ are higher than the PAAS composition for most of the sediments, with shales and wackes having strikingly higher values than the observed for the composition of the continental crust (Figure 7). Fe-sands, litharenites and sublitharenites tend to be depleted in $\mathrm{Co}$ and $\mathrm{Ni}$, while the presence of those elements are more common for the studied shales and wackes than for the post-archean Australian shale. Shales and wackes have V, Sc and $\mathrm{Cu}$ values in their composition similar to slightly depleted in relation to the PAAS composition.

Other sediments in the study area are depleted in $\mathrm{Sc}$ and highly depleted in $\mathrm{V}$ and $\mathrm{Cu}$. A strong positive correlation coefficient between $\mathrm{Ni}, \mathrm{V}, \mathrm{Sc}$ and $\mathrm{Cu}$ and $\mathrm{Al}_{2} \mathrm{O}_{3}, \mathrm{Fe}_{2} \mathrm{O}_{3}$ and $\mathrm{K}_{2} \mathrm{O}$ (Table 3) indicates those elements are mainly concentrated in the phyllosilicates and clay minerals.

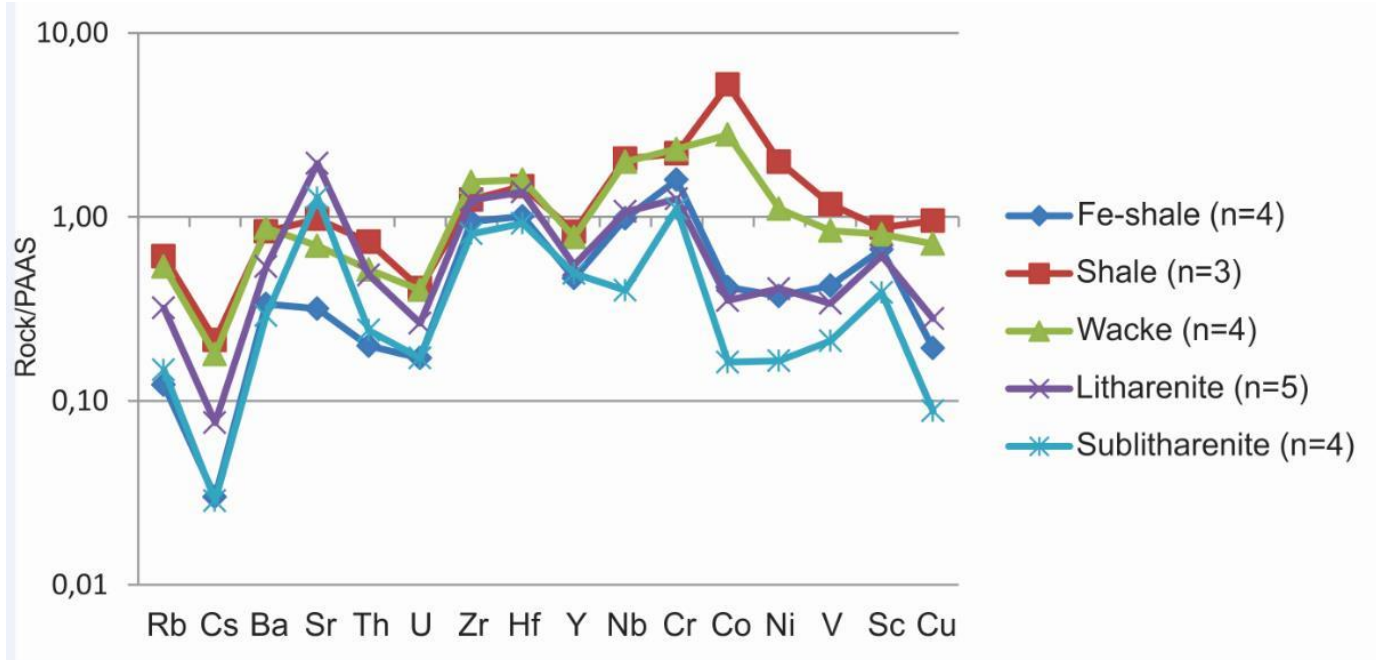

Figure 7 - Post-Archean Australian shale (PAAS) normalized values for the trace elements from the Bauru Basin rocks in the studied area 


\section{Rare Earth Elements (REE)}

In general, Fe-sands, litharenites and sublitharenites are depleted in rare earth elements (REE) when compared with the PAAS composition. Light Rare Earth Elements (LREE) are more available in the composition of shales and wackes than in the upper continental crust composition, whereas the Heavy Rare Earth
Elements (HREE) are more present in the postarchean Australian shale than in the sediments of the Bauru Basin in the study area (Table 3). Rare Earth Elements are positively correlated with $\mathrm{Al}_{2} \mathrm{O}_{3}, \mathrm{Fe}_{2} \mathrm{O}_{3}$ and $\mathrm{K}_{2} \mathrm{O}$. As for the trace elements, the positive relation between REE and those major elements points towards a main concentration in phyllosilicates (Figure 8).

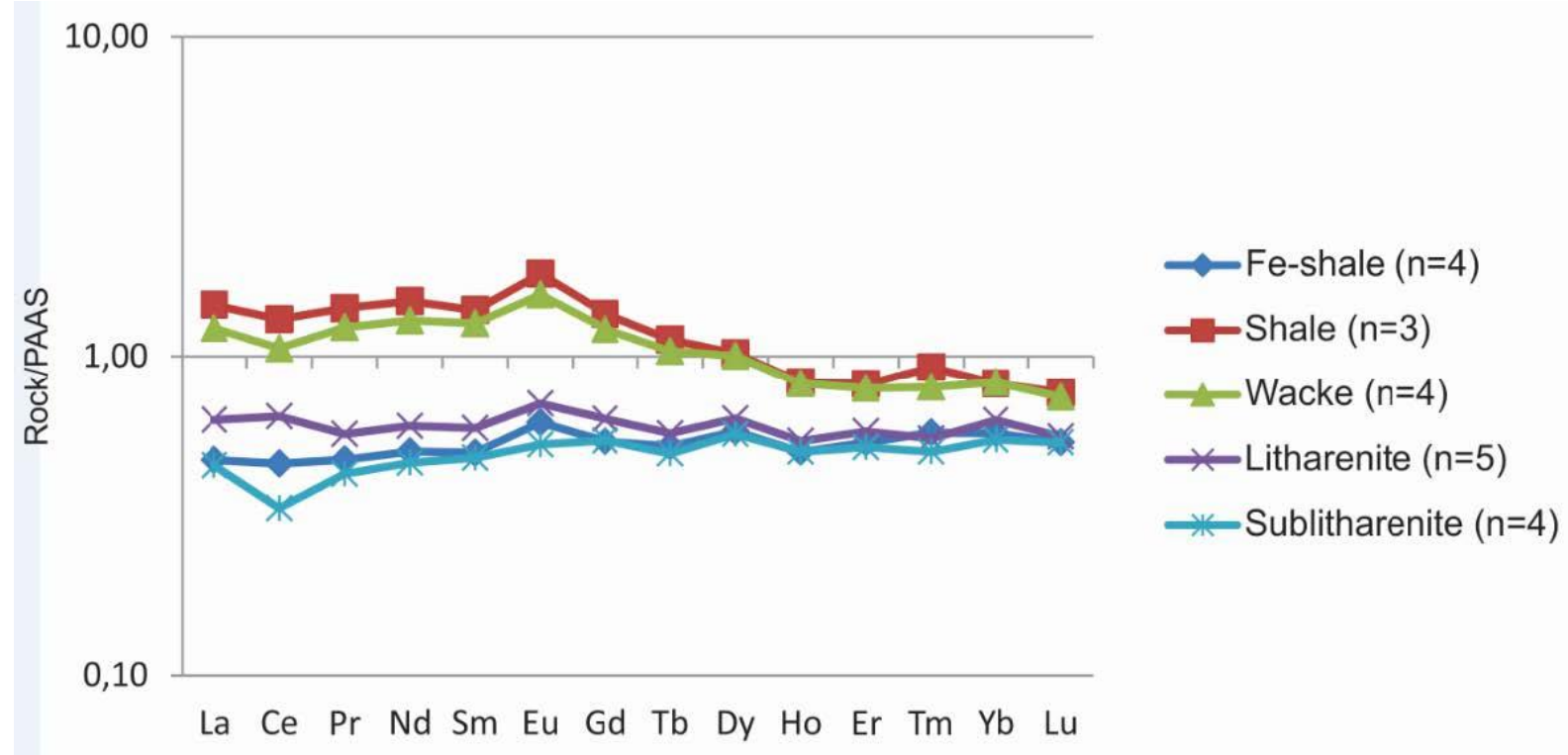

Figure 8 - Post-Archean Australian shale (PAAS) normalized values for the Rare Earth elements from the Bauru Basin rocks in the studied area.

\section{TECTONIC SETTING, PROVENANCE AND WEATHERING IN THE BAURU BASIN}

Sediments and sedimentary rocks composition are affected by three interrelated components: tectonic setting, climate and the depositional system nature (Cox et al., 1995; Fralick \& Kronberg, 1997; McLennan, 1989; Nesbitt \& Young, 1996). Since their composition also varies with time, geochemical characteristics may be applied to a comprehension of the evolving mechanisms of the Earth (Taylor \& McLennan, 1985), being useful for the determination of depositional setting and associated provenance.

This section aims to describe the main influence of the geochemistry in the tectonic setting, provenance and composition of sedimentary rocks in the Bauru Basin, which suggest that even if the interaction of these factors is complex, the sedimentary behaviour is similar in certains geological settings (Akarish \& El-Gohary, 2011; Dickinson \& Suczek, 1979; Dickinson et al., 1983; Mishra \& Sen, 2012).

\section{Tectonic Setting}

Major and trace elements were used in this work to discriminate the source area related to its tectonic setting (Figures 9 to 12) (Bhatia \&
Crook, 1986; Roser \& Korsch, 1986; Hossain et al. 2010, Akarish \& El-Gohary 2011, Mishra \& Sen, 2012 and Roy \& Roser, 2013). Figure 9 shows a Th-Sc-Zr/10 diagram (Bhatia \& Crook, 1986).

The interpretation of this tectonic setting diagram is expanded, as the passive continental margin field can also represent sedimentary rocks derived from stable continental areas and deposited in intracratonic basins (Mishra \& Sen, 2012). $\mathrm{A} \mathrm{K} \mathrm{K}_{2} \mathrm{O} / \mathrm{Na}_{2} \mathrm{O}$ versus $\mathrm{SiO}_{2}$ diagram also determined the tectonic setting for sediments deposited in the Bauru Basin (Figure 10) (Roser \& Korsch, 1986; Roser \& Korsch, 1988). Both plots indicate that studied samples plot into the continental passive margin field, indicating they derive from a stable tectonic setting such as an intracratonic basin.

\section{Provenance}

Major elements were used to determine the sedimentary provenance through a Discrimination Function Analysis diagram, representing four possible source rocks for the Bauru Basin: mafic igneous (P1), intermediate (P2), felsic (P3) and quartzose sedimentary rocks 
(P4) (Figure 11) (Roser \& Korsch, 1988). The term "Quartzose Recycled sediments", originally proposed for P4, was substituted by Quartzose Sedimentary Rocks (Meinhold et al., 2007; Hossain et al., 2010; Roy \& Roser, 2013). Most of Bauru Basin samples plot in the P4 field, equivalent to a quartzitic or an intensely weathered granitic-gneissic terrane, or a recycled sedimentary source area (Roser \& Korsch, 1988). Recycling effects represent a progressive loss of phyllosilicatic minerals such as feldspars and an increase in quartz contents. This observation also rules a minimal possibility of the mafic rocks role as a source rock for the studied samples.

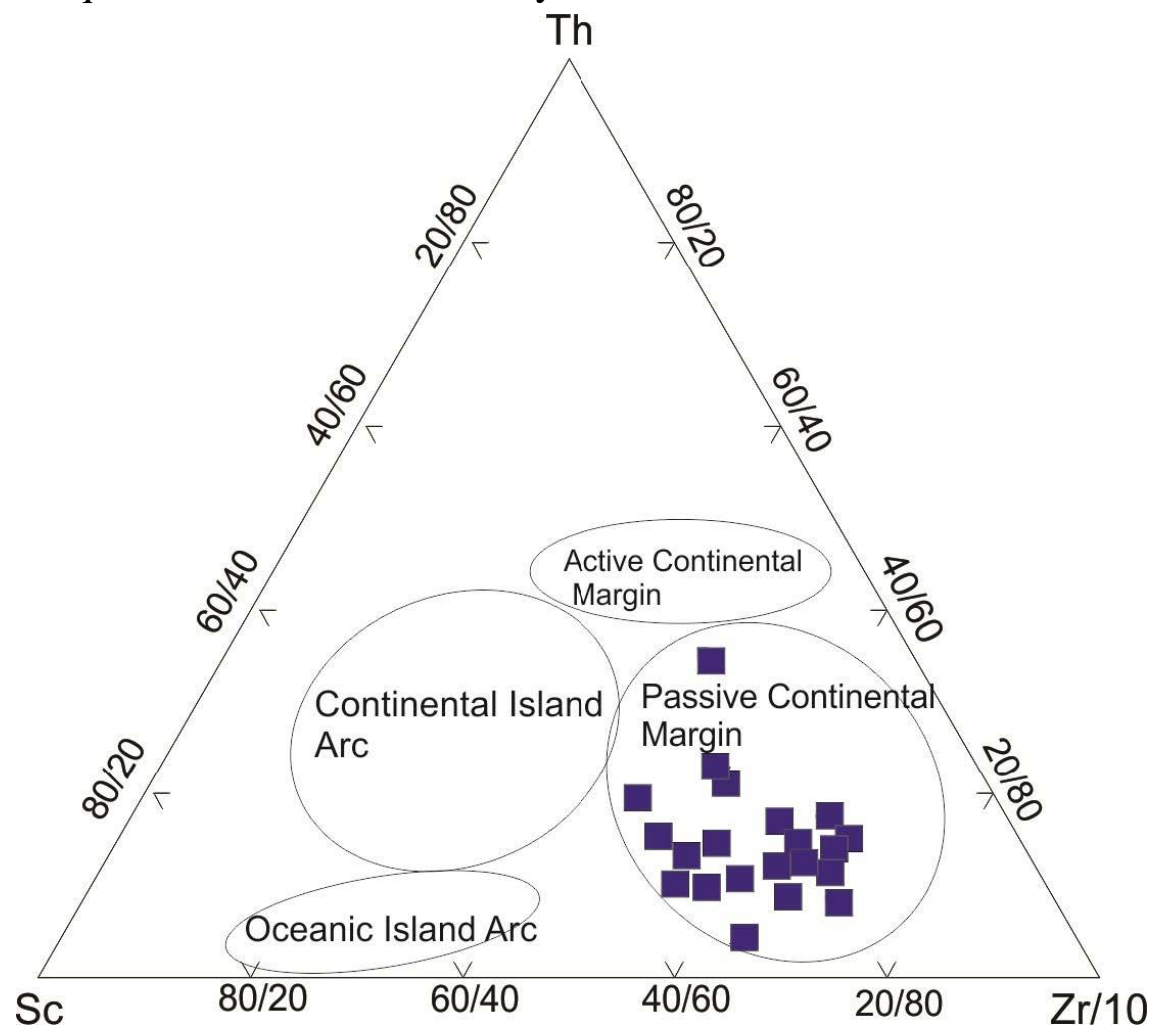

Figure 9 - Plot of the mean compositions of the samples from Bauru Basin in the Th-Sc-Zr/10 diagram (after Bhatia \& Crook, 1986). All the samples plot into the Passive Continental Margin field.

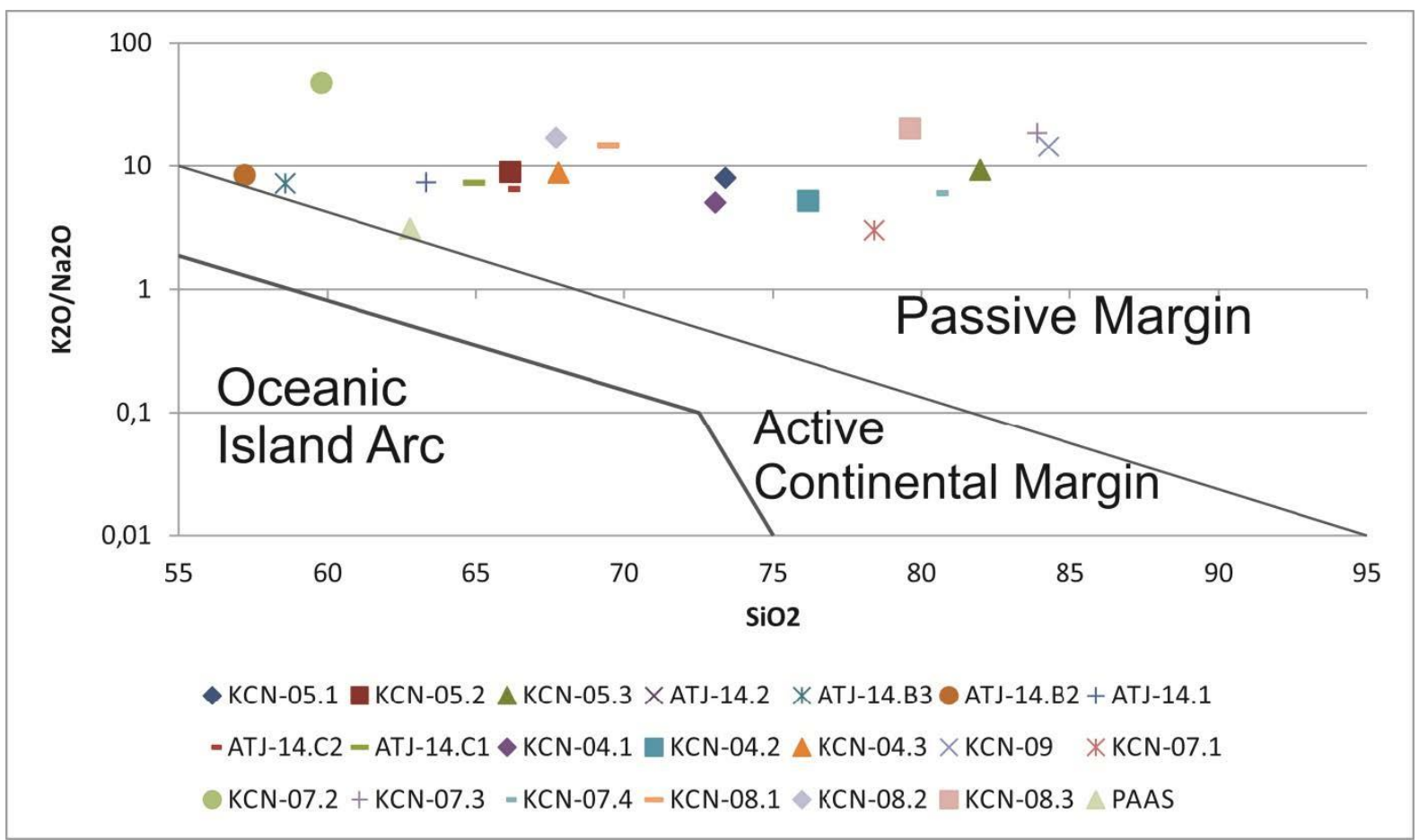

Figure $10-\mathrm{K}_{2} \mathrm{O} / \mathrm{Na}_{2} \mathrm{O}$ versus $\mathrm{SiO}_{2}$ tectonic setting discrimination diagram (after Roser \& Korsch, 1986) evidencing that samples from Bauru Basin plot on the continental passive margin field. 
Trace and Rare Earth elements tend to be immobile during weathering, transportation and deposition and are not affected by secondary processes after deposition such as diagenesis and metamorphism. Sediments from the Bauru Basin have high concentrations of $\mathrm{Zr}$ and $\mathrm{Hf}$.

Those elements have a high positive correlation coefficient, suggesting a zircon abundance in the studied area, which along with the mineralogical maturity relate to a felsic or reworked sediment source (Bauluz et al., 2000). $\mathrm{A} \mathrm{Zr} / \mathrm{Hf}$ ratio ranging between 31.89 to 46.84 for the Bauru Basin rocks contrasts with the average ratio for the post-archean Australian Shale (42), which also indicate that sediments from the Bauru Basin derive either from felsic source or from sediment recycling during transportation. $\mathrm{Hf}$ abundance was also analysed through a $\mathrm{La} / \mathrm{Th}$ versus Hf diagram (Figure 12) (Floyd \& Leveridge, 1987).

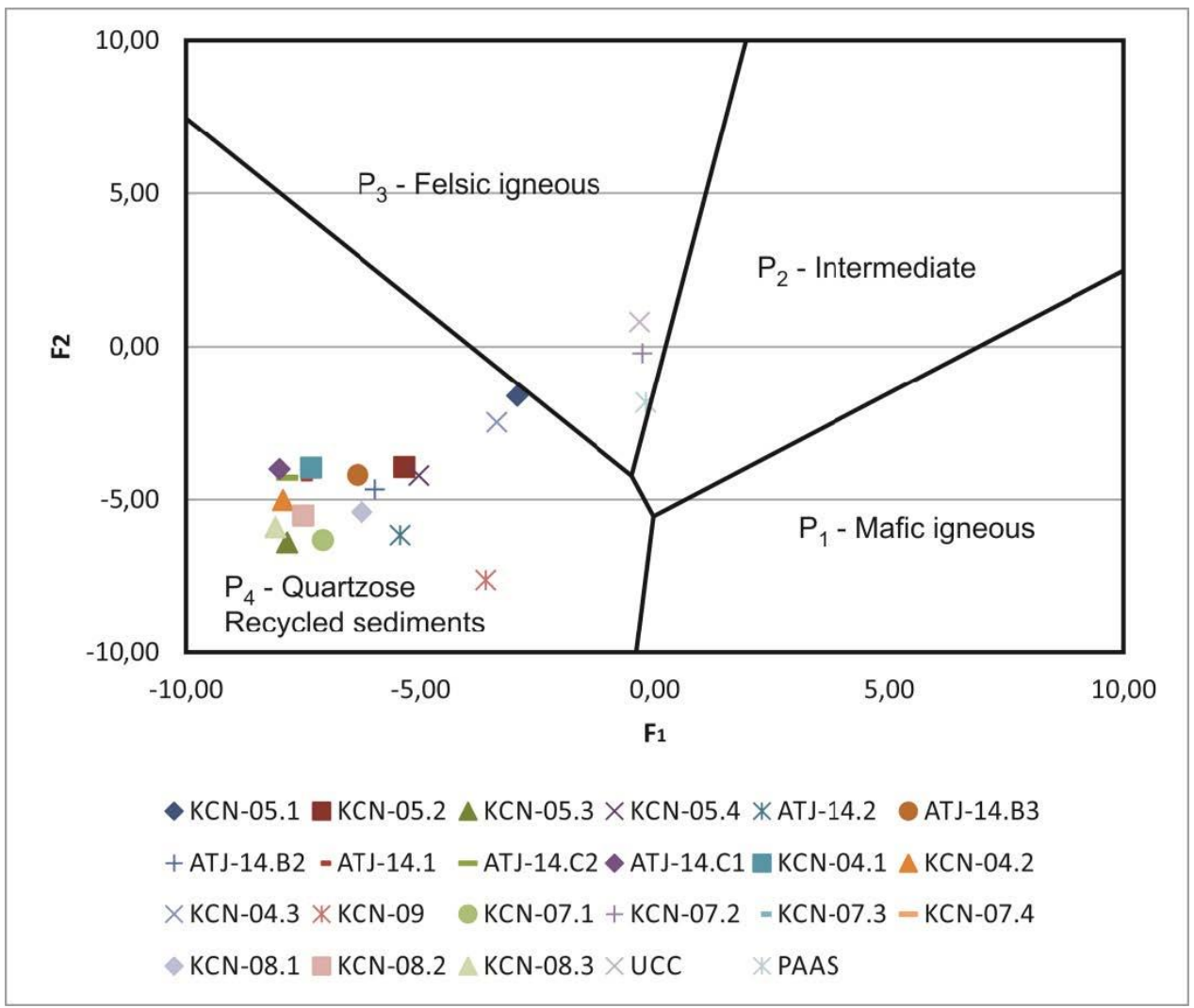

Figure 11 - Discriminant function analysis plot (Roser \& Korsch, 1988) for the Bauru Basin sediments. It is possible to observe that most of studied rocks and sediments plot into the Quartzose Recycled sediment (P4) field.

Values of Hf for Bauru Basin samples in the studied area vary from 3.1 to $9.5 \mu \mathrm{g} / \mathrm{g}$, while sediments show a low $\mathrm{La} / \mathrm{Th}$ ratio values. Results from this diagram indicate the sediments from the Bauru Basin derive from an ancient recycled sedimentary component and points to a minor influence of felsic rocks. Ratios including $\mathrm{Ba} / \mathrm{Co}$ (Cullers et al., 1988; Taylor \& McLennan, 1985), $\mathrm{Zr} / \mathrm{Sc}$ (McLennan, 1989), Cr/Ni (Garver et al., 1996), and $\mathrm{Th} / \mathrm{Sc}$, Th/Co and $\mathrm{Th} / \mathrm{Cr}$ (Cullers, 1994; Cullers et al., 1988; Hossain et al., 2010; McLennan et al., 1990; Wronkiewicz \& Condie, 1987) also indicate that sediments from the Bauru Basin are derived from felsic rocks exposed to weathering and undergone sediment recycling when transported to basin.

Rare Earth Elements have low residence time ( $<1000$ years) and low solubility at sea and river waters (Piper, 1974; Taylor \& McLennan, 1985), being mainly transported as particulate material, and suggesting these elements are mainly transferred to clastic sedimentary rocks (Taylor et al., 1981). REE ratios as $(\mathrm{La} / \mathrm{Yb})_{c}, \mathrm{La} / \mathrm{Sc}$, $\mathrm{Eu} / \mathrm{Eu}^{*}$ and LREE/HREE (Table 4) are significantly differentiated among mafic and felsic source rocks, thus offering information related to the sedimentary provenance and allowing the source rock discrimination even when sedimentary recycling is an important factor to consider (Armstrong-Altrin et al., 2004; Cox et al., 1995; Cullers, 2000, 1994; Cullers et al., 1988; McLennan et al., 1990; Rudnick \& Gao, 2003; Wronkiewicz \& Condie, 1987). Values for the $(\mathrm{La} / \mathrm{Yb})_{\mathrm{c}}$ and $\mathrm{La} / \mathrm{Sc}$ in the studied area relate to the values from Cullers (1994, 2000) and Cullers et al. (1988) for felsic rocks. 
Felsic rocks have high LREE/HREE ratios and negative Eu anomalies (Cullers, 1994; Cullers et al., 1988). Eu depletion is a result of intracrustal differentiation, associated with the felsic rocks production (McLennan, 1989). In the Bauru Basin, $\quad \mathrm{Eu} / \mathrm{Eu}^{*}, \quad(\mathrm{La} / \mathrm{Yb})_{\mathrm{c}}, \quad \mathrm{La} / \mathrm{Sc}$ and LREE/HREE ratios are similar to sediments derived from felsic sources.

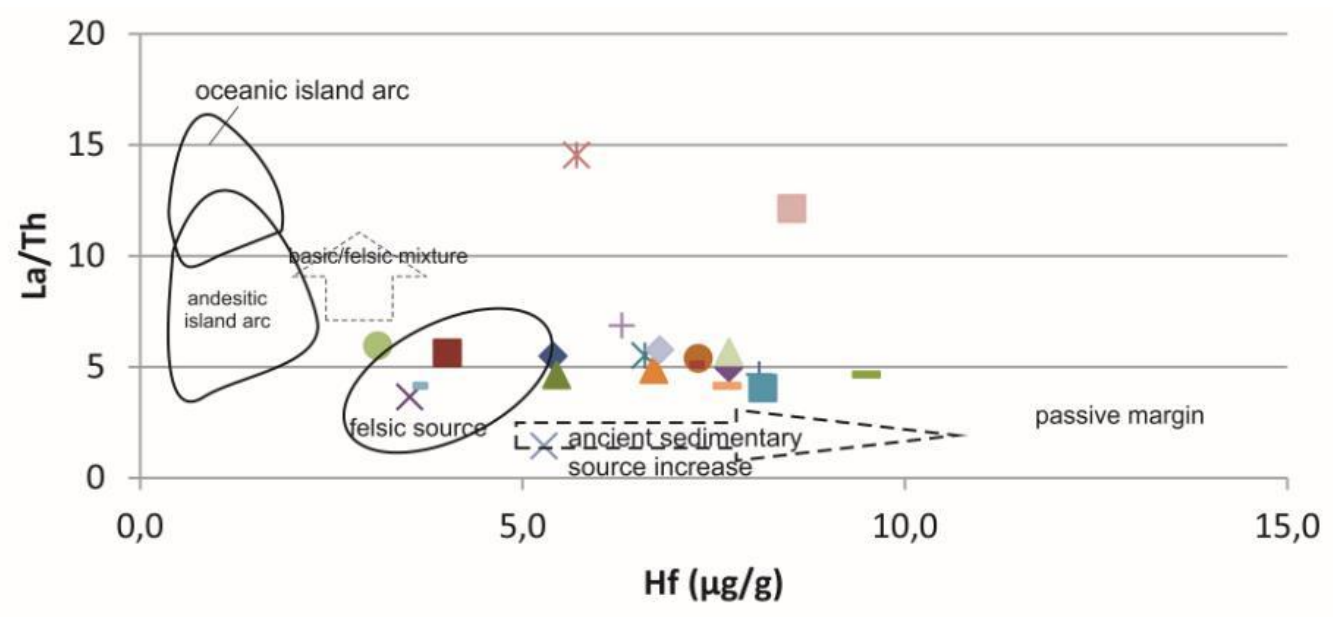

KCN-05.1 $\square$ KCN-05.2 $\triangle$ KCN-05.3 × KCN-05.4 * ATJ-14.2 ATJ-14.B3

+ ATJ-14.B2 -ATJ-14.1 -ATJ-14.C2 ATJ-14.C1 $\square$ KCN-04.1 $\triangle$ KCN-04.2

KCN-04.3 $*$ KCN-09 KCN-07.1 + KCN-07.2 - KCN-07.3 - KCN-07.4

$\mathrm{KCN}-08.1 \square \mathrm{KCN}-08.2 \triangle \mathrm{KCN}-08.3$

Figure 12 - Compositional and tectonic discrimination diagram using the La/Th ratio in relation to Hf (Floyd \& Leveridge, 1987), showing that samples from Bauru Basin are mainly influenced by the increase of ancient sedimentary component and a felsic content.

Table 4 - Elemental ratios for sedimentary rocks from Bauru Basin at the study area compared to PAAS, felsic and mafic rocks values.

\begin{tabular}{|c|c|c|c|c|c|c|c|}
\hline & Th/Sc & Th/Co & $\mathrm{Th} / \mathrm{Cr}$ & $(\mathbf{L a} / \mathbf{Y b}) \mathbf{c}$ & $\mathrm{La} / \mathrm{Sc}$ & $\mathbf{E u} / \mathbf{E u} *$ & LREE/HREE \\
\hline PAAS(a) & 0,75 & 0,63 & 0,13 & 9,2 & 2,37 & 0,65 & 8,89 \\
\hline $\begin{array}{l}\text { Variation for felsic } \\
\text { rocks(b) }\end{array}$ & $0,84-20,5$ & $0,67-19,4$ & $0,13-2,7$ & $3,0-27,0$ & $2,5-16,3$ & $0,40-0,94$ & --- \\
\hline $\begin{array}{l}\text { Variation for mafic } \\
\text { rocks(b) }\end{array}$ & $0,05-0,22$ & $0,04-1,4$ & $0,018-0,046$ & $1,1-7,0$ & $0,43-0,86$ & $0,71-0,95$ & --- \\
\hline Obtained values(c) & $0,1-1,91$ & $0,04-1,92$ & $0,008-0,14$ & $3,86-120,44$ & $1,47-4,86$ & $0,62-0,92$ & $2,75-13,95$ \\
\hline $\begin{array}{l}\text { Average values } \\
(\mathrm{n}=21)(\mathrm{c})\end{array}$ & $0,62 \pm 0,08$ & $0,53 \pm 0,10$ & $0,037 \pm 0,005$ & $52,26 \pm 7,34$ & $3,0 \pm 0,26$ & $0,76 \pm 0,02$ & $9,40 \pm 0,60$ \\
\hline
\end{tabular}

(a) Taylor \& McLennan (1985)

(b) Cullers (1994, 2000), Cullers et al. (1988)

(c) This work

From the geochemical analysis of major, trace and Rare Earth Elements, the provenance of the sediments in the Bauru Basin are explained by a system dominated by detritus originated from highly weathered granite-gneissic materials, which also agrees with the recent literature for the Bauru Basin.

\section{Weathering}

The Chemical Index of Alteration (CIA; Nesbitt \& Young, 1982) evaluates the progressive alteration of plagioclase and $\mathrm{K}$ feldspars to clay minerals. This index works when $\mathrm{Ca}, \mathrm{Na}$ and $\mathrm{K}$ decreases as the intensity of weathering increases (Nesbitt \& Young, 1984). CIA values are obtained by the equation: $\mathrm{CIA}=$ $\left[\mathrm{Al}_{2} \mathrm{O}_{3} /\left(\mathrm{Al}_{2} \mathrm{O}_{3}+\mathrm{CaO}^{*}+\mathrm{Na}_{2} \mathrm{O}+\mathrm{K}_{2} \mathrm{O}\right)\right] \times 100$, where $\mathrm{CaO}^{*}$ is the quantity of $\mathrm{CaO}$ assimilated in the silicate portion of the rock, with all major oxides expressed in molar proportions.

As there is no direct method to discriminate and quantify the $\mathrm{CaO}$ from the silicate fraction and non-silicate fractions, corrections of the $\mathrm{CaO}$ amount on $\mathrm{Ca}$ in carbonates and phosphates are calculated from measured $\mathrm{CO}_{2}$ and $\mathrm{P}_{2} \mathrm{O}_{5}$ contents. Due to the absence of $\mathrm{CO}_{2}, \mathrm{CaO}^{*}=\mathrm{CaO}$ - 10/3 x $\mathrm{P}_{2} \mathrm{O}_{5} . \mathrm{CaO}^{*}$ are accepted when the molar 
proportion is smaller than the values of $\mathrm{Na}_{2} \mathrm{O}$. When $\mathrm{CaO}^{*}$ is greater than $\mathrm{Na}_{2} \mathrm{O}$, it is assumed to be equivalent to $\mathrm{Na}_{2} \mathrm{O}$ values in the silicate fraction (McLennan, 1993).

The CIA values for the average shale ranges from 70 to 75 , indicating a moderately weathered source and reflecting the occurrence muscovite, illite and smectite clays.

Intensely weathered rocks have a CIA value close to 100 and reflect kaolinite and chlorite content and a complete depletion in alkaline and alkaline earth elements (McLennan, 1993; Nesbitt \& Young, 1982). The calculated CIA for the study area in the Bauru Basin varies from 64, 83 to 92,3 with an average of 74,34 . These values indicate a moderate to intense level of weathering. In the $\mathrm{Al}_{2} \mathrm{O}_{3}-\left(\mathrm{CaO}^{*}+\mathrm{Na}_{2} \mathrm{O}\right)-\mathrm{K}_{2} \mathrm{O}$ ternary diagram (Figure 13) most of values from the Bauru Basin plot in a tight group next to the $\mathrm{A}-\mathrm{K}$ axis close to muscovite and illite points, suggesting Al-enrichment during diagenesis and the conversion of unstable minerals, for example, feldspars and mica, in clay minerals (McLennan et al., 1993).

The Chemical Index of Weathering (CIW; Harnois, 1988) includes only the major elements with a consistent geochemical behaviour during weathering, with the following equation: $\mathrm{CIW}=$ $\left[\mathrm{Al}_{2} \mathrm{O}_{3} /\left(\mathrm{Al}_{2} \mathrm{O}_{3}+\mathrm{CaO}^{*}+\mathrm{Na}_{2} \mathrm{O}\right)\right] \times 100$, with all major oxides expressed in molar proportions. Alteration profiles derived from granitic rocks have CIW values ranging from 59 (fresh rock) to 98 (most weathered rock), while those values of sandstones and mudstones from the Bauru Basin range from 84.0 to 98.2 (average $=91.6$ ).

This result indicates a moderate to intense weathering degree in the source ares, corresponding to a semiarid climate and agrees with another geochemical dataset from rocks and paleosols from the Bauru Basin (Pereira et al., 2015; Silva et al., 2016; 2017a e b; Delgado et al., 2019).

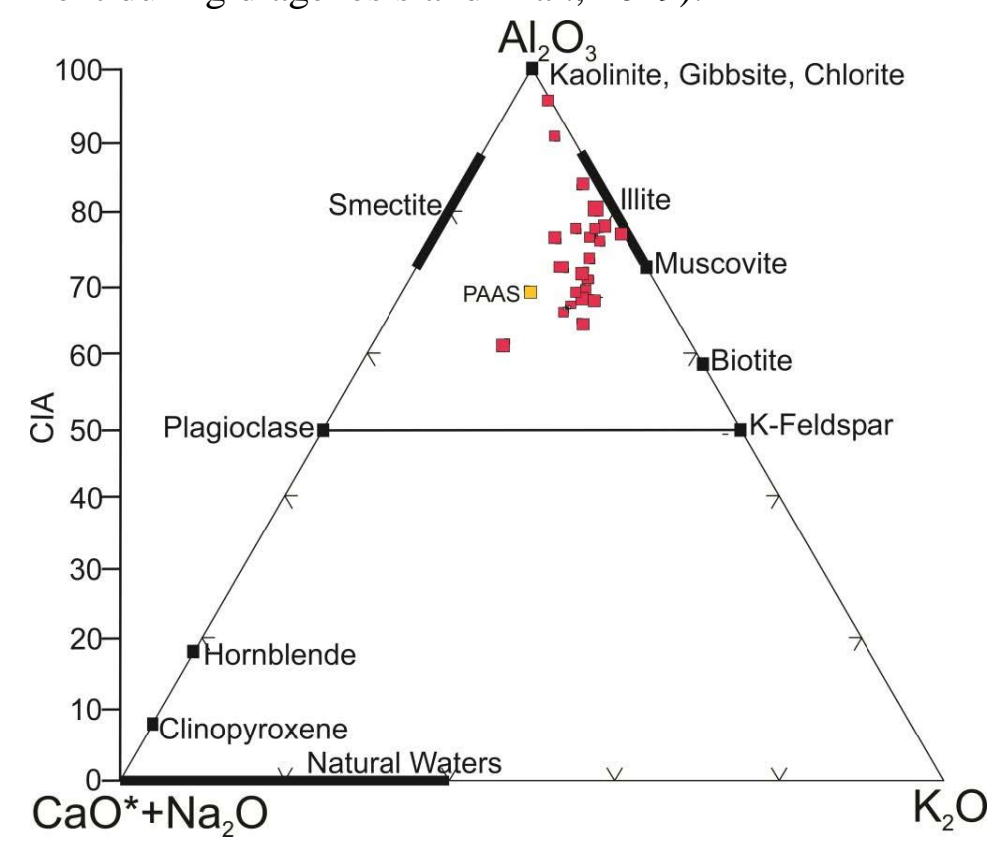

Figure 13 - Ternary $\mathrm{Al}_{2} \mathrm{O}_{3}-\left(\mathrm{CaO}^{*}+\mathrm{Na}_{2} \mathrm{O}\right)-\mathrm{K}_{2} \mathrm{O}$ plot (after Nesbitt \& Young, 1984; McLennan, 1993). Plotted are estimates of Bauru Basin sedimentary rocks considered in this study. Also plotted is the average Post-Archean Australian Shale (PAAS - Taylor \& McLennan, 1985). Shown at the left side is the CIA scale.

\section{DISCUSSION AND CONCLUSIONS}

During the Mesozoic alkaline intrusions in this now recognized as the limits between the Bauru Basin and the Sanfranciscan Basin to the $\mathrm{NE}$, the pre-Cambrian basement comprised essentially by rocks attributed to a granitic complex at $\mathrm{W}$; by the metasediments (paragneiss, schists, quartzites and fillites) from Araxá Group at the northeast and central portions and Bambuí Group rocks at the eastern was undergone a reactivation episode denominated Alto Paranaíba
Uplift (Hasui, 1968; Hasui \& Haralyi, 1981; Batezelli \& Ladeira, 2016).

The Uplift of the E and NE edges generated accommodation space and resulted in the initial configuration of Bauru Basin. The deformation of the NE edge exposed rocks from Serra Geral and Botucatu formations and the alkaline intrusions from Alto Paranaíba Uplift and Goiás Alkaline Province, constituting the sedimentary filling of the outermost Uberaba Formation 
(Gravina et al., 2002; Batezelli, 2010). The source area of sediments from the Bauru Basin passed through constant modifications during its evolution, as demonstrated in the palaeoenvironmental evolution model to the study area (Figure 14).

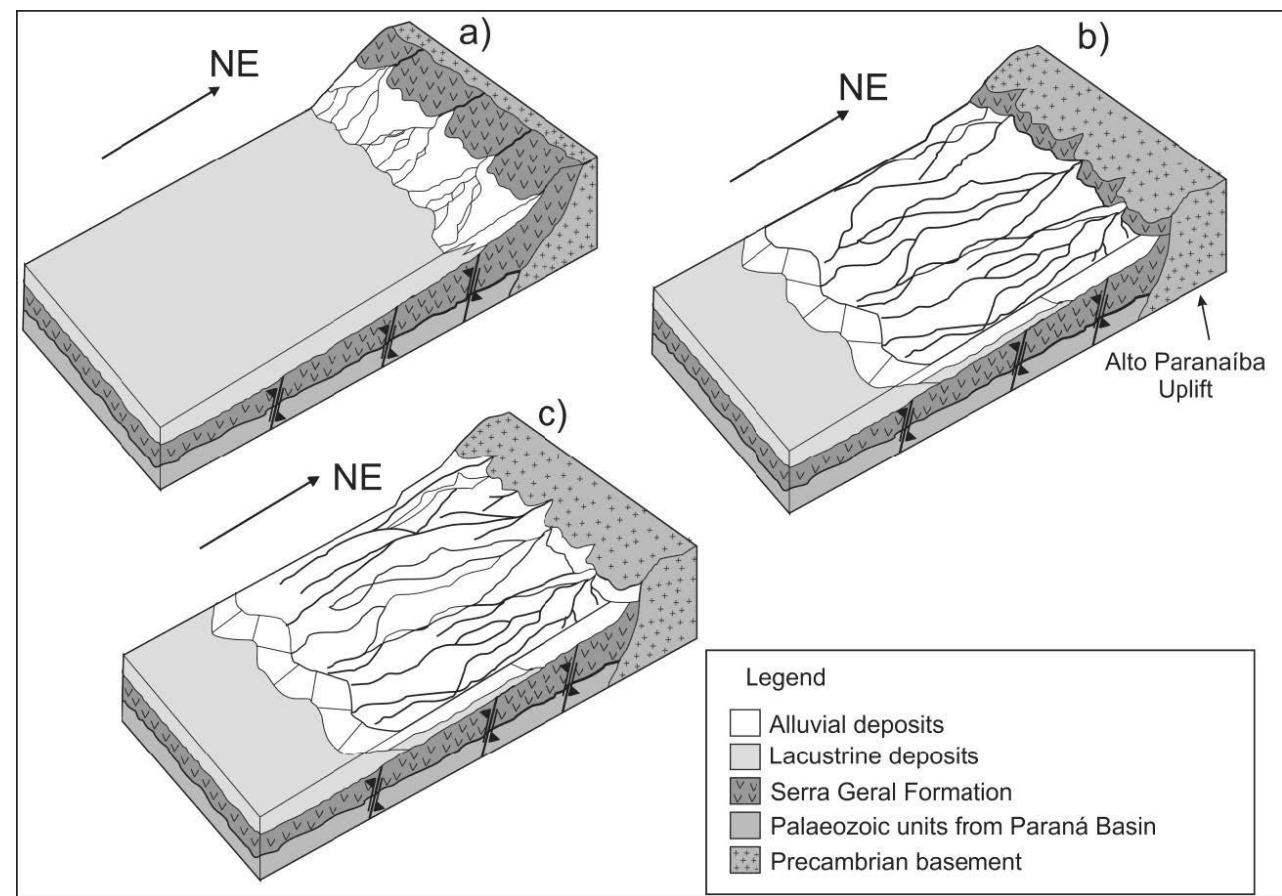

Figure 14 - Palaeoenvironmental evolution model for Bauru Basin at the study area. a) Beginning of alkaline intrusions on the $\mathrm{E}$ and NE edges, generating accommodation space for Bauru Basin sediments. Alkaline intrusions also resulted in the cropping of rocks from Serra Geral Formation and the Precambrian Basement. b) Alto Paranaíba Arc Uplift and the establishment of alluvial systems tract over the lacustrine deposits. c) Complete erosion of alkaline rocks, revealing that rocks from the granitic-gneiss Precambrian Basement is the main sedimentary source for the study area.

Progressively, rocks constituting the edges of Bauru Basin have been susceptible to weathering and erosional processes.

Sedimentary rocks analysed in this study and corresponding to the fluvial, and alluvial facies associations (Adamantina and Marília formations) exhibit a felsic nature, compatible with the outcropping of rocks from the quartzose Precambrian basement. Compositional maturity of sandstones deposited in Bauru Basin came either from the siliceous nature of source rocks from the basement and recycle of sediments in the sedimentary basin by ephemerals or perennial fluxes, as determined by the geochemical analysis for the studied area. Petrographic analysis of rocks from the fluvial and alluvial facies association in the northern and central Bauru Basin (Batezelli, 2003; Batezelli et al., 2005), and paleocurrent data from cross stratification on sandstones (Batezelli et al. 2007, Batezelli 2010; Batezelli, 2015; Batezelli \& Ladeira, 2016; Batezelli et al., 2019) indicates a sedimentary inflow coming from the NE portion of Bauru Basin. Mudstones deposition through temporary streams flow into a depression and carry with them a suspended load of clay and silt which was deposited in the still water. Sedimentary deposition of Bauru Basin reflects an interaction of aeolian and lacustrine processes similar to those from the mid-Holocene Gobi Mongolia Basin (Grunert et al., 2009) and the Permian Rotliegend Group from the Netherlands (McKie, 2011).

The main results from this paper proves that the geochemical fingerprint of sediment and sedimentary rocks is a reliable source for understanding the evolution and infill of a sedimentary basin. Here, sediments from the Bauru Basin were classified into $\mathrm{Fe}$-sands, litharenites, sublitharenites, shales and wackes, with a chemical composition that either correlated or not with the post-Archean Australian shale. Ratios between major trace and Rare Earth elements and diagrams showed that rocks for the studied area had a strong affiliation with recycled sedimentary rocks, quartzos e rocks and felsic rocks, weathered at semi-arid conditions. Those results are aligned with the literature on the evolution of the Bauru Basin during the Late Cretaceous. 


\section{ACKNOWLEDGEMENTS}

The authors wish to thank the CAPES Foundation (Coordenação de Aperfeiçoamento de Pessoal de Nivel Superior), for the MSc. research grant to the first author from 2012 to 2014, and the São Paulo Research Foundation (FAPESP) for supporting and funding Project FAPESP 2015/17632-5: Sedimentation and pedogenesis of the Upper Cretaceous of the Bauru, Sanfranciscana, Parecis and Neuquen basins. The second author thanks to $\mathrm{CNPq}$ for the productivity grants (process 301200/2017-3).

\section{REFERENCES}

AKARISH, A.I. \& EL-GOHARY, A.M. Provenance and Source Area Weathering Derived from the Geochemistry of PreCenomanian Sandstones, East Sinai, Egypt. J. Appl. Sci., v. 11, p. 3070-3088, 2011.

ARMSTRONG-ALTRIN, J.S., LEE, Y. IL, VERMA, S.P., RAMASAMY, S. Geochemistry of sandstones from the upper Miocene Kudankulam Formation, southern India: Implications for provenance, weathering, and tectonic setting. J. Sediment. Res., v. 74, p. 285-297, 2004.

BATEZELLI, A. Análise da sedimentação cretácea no Triângulo Mineiro e sua correlação com áreas adjacentes. Universidade Estadual Paulista. 2003

BATEZELLI, A. Arcabouço tectono-estratigráfico e evolução das Bacias Caiuá e Bauru no Sudeste brasileiro. Revista Brasileira de Geociências, v. 40, p. 265-285, 2010.

BATEZELLI, A. Continental systems tracts of the Brazilian Cretaceous Bauru Basin and their relationship with the tectonic and climatic evolution of South America. Basin Res., 29, 1-25, 2015.

BATEZELLI, A. \& LADEIRA, F.S.B. Stratigraphic framework and evolution of the Cretaceous continental sequences of the Bauru, Sanfranciscana, and Parecis Basins, Brazil. Journal of South America Earth Sciences, v. 65, n. 1-24, 2016.

BATEZELLI, A.; GOMES, N.S.; PERINOTTO, J.A., Petrografia e evolução diagenética dos arenitos da porção norte e nordeste da Bacia Bauru (Cretáceo Superior). Brazilian J. Geol., v. 35 , p. 311-322, 2005.

BATEZELLI, A.; LADEIRA, F.S.B.; NASCIMENTO, D.L.; SILVA, M.L. Facies and palaeosol analysis in a progradational distributive fluvial system from the Campanian-Maastrichtian Bauru Group, Brazil. Sedimentology, v. 66, n. 2, p. 699-735, 2019.

BATEZELLI, A.; SAAD, A.R.; BASILICI, G., Arquitetura deposicional e evolução da sequência aluvial neocretácea da porção setentrional da Bacia Bauru, no sudeste brasileiro. Revista Brasileira Geociências, v. 37, p. 163-181, 2007.

BAULUZ, B.; MAYAYO, M.J.; FERNANDEZ-NIETO, C.; MANUEL, J.; LOPEZ, G. Geochemistry of Precambrian and Paleozoic siliciclastic rocks from the Iberian Range (NE Spain): implications for source-area weathering, sorting, provenance, and tectonic setting. Chem. Geol. v. 168, p. 135-150, 2000.

BHATIA, M.R. \& CROOK, K.A.W. Trace element characteristics of graywackes and tectonic setting discrimination of sedimentary basins. Contrib. to Mineral. Petrol., v 92, p. 181-193, 1986.

CONDIE, K.C. \& WRONKIEWICZ, D.J. A new look at the Archaean-Proterozoic boundary sediments and the tectonic setting constraint. Dev. Precambrian Geol. v. 8, p. 61-83, 1990.

CONDIE, K.C.; LEE, D.; FARMER, G.L. Tectonic setting and provenance of the Neoproterozoic Uinta Mountain and Big Cottonwood groups, northern Utah: constraints from geochemistry, $\mathrm{Nd}$ isotopes, and detrital modes. Sediment. Geol. v. 141-142, p. 443-464, 2001.

COX, R.; LOWE, D.R.; CULLERS, R. The influence of sediment recycling and basement composition on evolution of mudrock chemistry in the southwestern United States. Geochim. Cosmochim. Acta, v. 59, p. 2919-2940, 1995.

CULLERS, R.L. The controls on the major and trace element variation of shales, siltstones, and sandstones of PennsylvanianPermian age from uplifted continental blocks in Colorado to platform sediment in Kansas, USA. Geochim. Cosmochim.
Acta, v. 58, p. 4955-4972, 1994.

CULLERS, R.L. The geochemistry of shales, siltstones and sandstones of Pennsylvanian-Permian age, Colorado, USA: implications for provenance and metamorphic studies. Lithos, v. 51, p. 181-203, 2000.

CULLERS, R.L.; BASU, A.; SUTTNER, L.J. Geochemical signature of provenance in sand-size material in soils and stream sediments near the Tobacco Root batholith, Montana, U.S.A. Chem. Geol. v. 70, p. 335-348, 1988

CULLERS, R.; CHAUDHURI, S.; KILBANE, N.; KOCH, R., Rare-earths in size fractions and sedimentary rocks of Pennsylvanian-Permian age from the mid-continent of the U.S.A. Geochim. Cosmochim. Acta, v. 43, p. 1285-1301, 1979.

DELGADO, L.; BATEZELLI A.; LADEIRA, F.S.B.; LUNA, J. Paleoenvironmental and paleoclimatic interpretation of the Late Cretaceous Marília Formation (Brazil) based on paleosol geochemistry. Catena, v. 180, p. 365-382, 2019.

DICKINSON, W.R. \& SUCZEK, C.A. Plate Tectonics and Sandstone Compositions. Am. Assoc. Pet. Geol. Bull., v. 63 , p. 2164-2182, 1979.

DICKINSON, W.R.; BEARD, L.S.U.E.; BRAKENRIDGE, G.R.; ERJAVEC, J.L.; FERGUSON, C.; INMAN, K.F.; KNEPP, R.E.X.A.; LINDBERG, F.A.; RYBERG, P.T. Provenance of North American Phanerozoic sandstones in relation to tectonic setting. Geol. Soc. Am. Bull. V. 94, p. 222-235, 1983.

FEDO, C.; NESBITT, H.; YOUNG, G., Unraveling the effects of potassium metasomatism in sedimentary rocks and paleosols, with implications for paleoweathering conditions and provenance. Geology, v. 23, p. 921-924, 1995.

FLOYD, P.A. \& LEVERIDGE, B.E. Tectonic environment of the Devonian Gramscatho basin, south Cornwall: framework mode and geochemical evidence from turbiditic sandstones. J. Geol. Soc. London, v. 144, p. 531-542, 1987.

FRALICK, P. \& KRONBERG, B. Geochemical discrimination of clastic sedimentary rock sources. Sediment. Geol. V. 113, p. 111-124, 1997.

GARVER, J.I., ROYCE, P.R., SMICK, T.A. Chromium and Nickel in Shale of the Taconic Foreland: A Case Study for the Provenance of Fine-Grained Sediments with an Ultramafic Source. J. Sediment. Res., v. 66, p. 100-106, 1965

GRAVINA, É.G.; KAFINO, C.V.; BROD, J.A.; BOAVENTURA, G.R.; SANTOS, R.V.; GUIMARÃES, E.D.I.M.; JOST, H. Proveniência de arenitos das formações Uberaba e Marília (Grupo Bauru) e do Garimpo do Bandeira: Implicações para a controvérsia sobre a Fonte do Diamante do Triângulo Mineiro. Revista Brasileira Geociências, v. 32, p. 545558,2002

GRUNERT, J.; STOLZ, C.; HEMPELMANN, N.; LEHMKUHL, F.; FELAUER, T.; HILGERS, A.; HUELLE, D. Interaction of aeolian and lacustrine processes in endorheic basins of the Gobi, Mongolia, new results. In: INTERNATIONAL GEOMORPHOLOGY CONFERENCE, 7, 2009. Actas...Gobi, 2009

HARNOIS, L. The CIW index: A new chemical index of weathering. Sediment. Geol. 55, 319-322, 1988.

HASUI, Y. \& HARALYI, N.L.E., Aspectos litoestruturais e geofísicos do Soerguimento do Alto Paranaíba. Geociências, v. 10, p. 67-77, 1981.

HASUI, Y. A Formação Uberaba. In: CONGRESSO BRASILEIRO 
DE GEOLOGIA, 22. Belo Horizonte. 1968. Anais...Belo Horizonte: Sociedade Brasileira de Geologia, 1968, p. 167-169.

HERRON, M.M. Geochemical Classification of Terrigenous Sands and Shales from Core or Log Data. J. Sediment. Res., v. 58, p. 820-829, 1988.

HOSSAIN, H.M.Z.; ROSER, B.P.; KIMURA, J.I. Petrography and whole-rock geochemistry of the Tertiary Sylhet succession, northeastern Bengal Basin, Bangladesh: Provenance and source area weathering. Sediment. Geol., v. 228, p. 171-183, 2010.

JARVIS, I.; MORETON, J.; GÉRARD, M., Chemostratigraphy of Madeira abyssal plain Miocene-Pleistocene turbidites, site 950. In: Proceedings of the Ocean Drilling Program. Scientific Results. Ocean Drilling Program, p. 535-558, 1998.

MCBRIDE, E.F. A classification of common sandstones. J. Sediment. Petrol. v. 33, p. 664-669, 1963.

MCKIE, T. A comparison of modern dryland depositional systems with the Rotliegend Group in the Netherlands. In: GRÖTSCH, J., GAUPP, R. (Eds.), The Permian Rotliegend of The Netherlands. p. 89-103. 2011.

MCLENNAN, S.M., Rare earth elements in sedimentary rocks; influence of provenance and sedimentary processes. Rev. Mineral. Geochemistry, v. 21, p. 169-200, 1989.

MCLENNAN, S.M., Weathering and global denudation. J. Geol. p. 295-303, 1993

MCLENNAN, S.M. \& TAYLOR, S.R. Sedimentary rocks and crustal evolution: tectonic setting and secular trends. J. Geol. v. 99, p. 1-21, 1991.

MCLENNAN, S.M.; HEMMING, S.; MCDANIEL, D.K.; HANSON, G.N. Geochemical approaches to sedimentation, provenance and tectonics, in: Johnsson, M.J., Basu, A. (Eds.), Processes Controlling the Composition of Clastic Sediments. Geological Society of America Special Paper 284, Boulder, Colorado, p. 21-40, 1993.

MCLENNAN, S.M.; NANCE, W.B.; TAYLOR, S.R., Rare earth element-thorium correlations in sedimentary rocks, and the composition of the continental crust. Geochim. Cosmochim. Acta, v. 44, p. 1833-1839, 1980.

MCLENNAN, S.; TAYLOR, S.; MCCULLOCH, M.; MAYNARD, J. Geochemical and Nd-Sr isotopic composition of deepsea turbidites: Crustal evolution and plate tectonic associations. Geochim. Cosmochim. Acta, v. 54, p. 2015-2050, 1990.

MEINHOLD, G.; KOSTOPOULOS, D.; REISCHMANN, T. Geochemical constraints on the provenance and depositional setting of sedimentary rocks from the islands of Chios, Inousses and Psara, Aegean Sea, Greece: implications for the evolution of Palaeotethys. J. Geol. Soc. London, v. 164, p. 1145-1163, 2007.

MILANI, E.J. Evolução tectono-estratigráfica da Bacia do Paraná e seu relacionamento com a geodinâmica Fanerozoica do Gondwana Sul-Ocidental. Porto Alegre, 1997. Tese (Doutorado), Universidade Federal do Rio Grande do Sul.

MISHRA, M. \& SEN, S., Provenance, tectonic setting and sourcearea weathering of Mesoproterozoic Kaimur Group, Vindhyan Supergroup, Central India. Geol. Acta 10, 283-293. 2012.

MONGELLI, G.; CRITELLI, S.; PERRI, F.; SONNINO, M.; PERRONE, V. Sedimentary recycling, provenance and paleoweathering from chemistry and mineralogy of Mesozoic continental redbed mudrocks, Peloritani mountains, southern Italy. Geochem. J. 40, 197-206, 2006.

NASCIMENTO, N.L.; LADEIRA, F.S.B.; BATEZELLI, A. Pedodiagenetic Characterization of Cretaceous Paleosols in Southwest Minas Gerais, Brazil. Revista Brasileira de Ciência do Solo, n. 41, e0160065, 2016.

NESBITT, H.W. \& YOUNG, G.M. Early Proterozoic climates and plate motions inferred from major element chemistry of lutites. Nature, v. 299, p. 715-717, 1982.

NESBITT, H.W. \& YOUNG, G.M. Prediction of some weathering trends of plutonic and volcanic rocks based on thermodynamic and kinetic considerations. Geochim. Cosmochim. Acta, v. 48, p. 1523-1534, 1984.

NESBITT, H.W., YOUNG, G.M. Petrogenesis of sediments in the absence of chemical weathering: effects of abrasion and sorting on bulk composition and mineralogy. Sedimentology, v 43, p. 341-358, 1996.

NESBITT, H.W.; MACRAE, N.D.; KRONBERG, B.I. Amazon deep-sea fan muds: light REE enriched products of extreme chemical weathering. Earth Planet. Sci. Lett., v. 100, p. 118123, 1990

PEARCE, T.J. \& JARVIS, I. High-resolution chemostratigraphy of Quaternary distal turbidites: a case study of new methods for the analysis and correlation of barren sequences. Geol. Soc. London, Spec. Publ., v. 89, p. 107-143, 1995.

PEREIRA, C.T.; BATEZELLI, A.; LADEIRA, F.S.B. Paleoprecipitation changes based on paleosols profiles of the Marília Formation (Upper Cretaceous) in the eastern portion of the Bauru Basin in southeastern Brazil. Revista Geociências, v. 34, n. 2, p. $238-257,2015$.

PIPER, D.Z. Rare earth elements in the sedimentary cycle: A summary. Chem. Geol. v. 14, p. 285-304, 1974.

ROSER, B.P. \& KORSCH, R.J. Determination of tectonic setting of sandstone-mudstone suites using $\mathrm{SiO}_{2}$-content and $\mathrm{K}_{2} \mathrm{O} / \mathrm{Na}_{2} \mathrm{O}$ ratio. J. Geol. v. 94, p. 635-650, 1986.

ROSER, B.P. \& KORSCH, R.J. Provenance signatures of sandstone-mudstone suites determined using discriminant function analysis of major-element data. Chem. Geol. v. 67, p. 119-139, 1988.

ROY, D.K. \& ROSER, B.P. Climatic control on the composition of Carboniferous-Permian Gondwana sediments, Khalaspir basin, Bangladesh. Gondwana Res., v. 23, p. 1163-1171, 2013. RUDNICK, R.L. \& GAO, S. Composition of the Continental Crust, in: Holland, H.D., Turekian, K.K. (Eds.), Treatise on Geochemistry. Elsevier, p. 1-64, 2003

SILVA, M.L.; BATEZELLI, A.; LADEIRA, F.S.B. Índices de intemperismo e evolução dos paleossolos da Formação Marília, Maastrichtiano da Bacia neocretácea Bauru. Geochimica Brasiliensis, v. 29, p. 127-138, 2015.

SILVA, M.L.; BATEZELLI, A.; LADEIRA, F.S.B. Uso de estimativas de paleoprecipitação e paleotemperatura em paleossolos cretáceos no Brasil: abordagem crítica. Geochimica Brasiliensis, v. 30, p. 72-83, 2016.

SILVA, M.L.; BATEZELLI, A.; LADEIRA, F.S.B. Micromorphology of paleosols of the Marília Formation and their significance in the paleoenvironmental evolution fo the Bauru Basin, Upper Cretaceous, southeastern Brazil. Revista Brasileira de Ciência do Solo, n. 41, e0160287, 2017a.

SILVA, M.L.; BATEZELLI, A.; LADEIRA, F.S.B. The mineralogy of paleosols in the Marília Formation and their importance in the environmental evolution of the Maastrichtian of the Bauru Basin in southeastern Brazil. Brazilian Journal of Geology, v. 47, n. 3, p.403-426, 2017 b.

TAYLOR, S.R. \& MCLENNAN, S.M. The continental crust: its composition and evolution. Blackwell Scientific Pub., Oxford, 1985.

TAYLOR, S.R.; MCLENNAN, S.M.; ARMSTRONG, R.L.; TARNEY, J. The Composition and Evolution of the Continental Crust: Rare Earth Element Evidence from Sedimentary Rocks [and Discussion]. Philos. Trans. R. Soc. A Math. Phys. Eng. Sci., v. 301, p. 381-399, 1981.

WRONKIEWICZ, D.J. \& CONDIE, K.C. Geochemistry of Archean shales from the Witwatersrand Supergroup, South Africa: source-area weathering and provenance. Geochim. Cosmochim. Acta, v. 51, p. 2401-2416, 1987.

YU, Z; ROBINSON, P.; MCGOLDRICK, P. An Evaluation of Methods for the Chemical Decomposition of Geological Materials for Trace Element Determination using ICP- MS. Geostand. Newsl., v. 25, p. 199-217, 2001

Submetido em 14 de setembro de 2015 Aceito em 3 de maio de 2019 